\title{
Appendix: List of treaties
}

\section{Introduction}

The list that follows is of some 200 treaties from the period c. 7001200 , which have formed the basis of this study on international law. They represent a selection of the available evidence from the period. The criteria of this selection are outlined briefly in the introduction and more fully in Chapter 1.

\section{Name and date of treaties}

As far as possible, treaties have been listed in alphabetical order using first and foremost the place where they were concluded, when the text has indicated this. Where the text supplies specific additional details, such as 'in the palace', these have been explained in the endnotes. Some texts carry no place, but where there is good narrative evidence of a treaty having been concluded in a particular place, this has been used. A similar approach has also been taken to dates.

In cases where several treaties have been concluded in the same place, a date has been placed in brackets, in this list as in the main text, so that the reader can distinguish which treaty is referred to. In those exceptional cases, where two or more treaties were concluded in the same place in the same year, a Roman numeral after the name has been used, e.g., Treaty of Genoa I.

Where no place can be securely deducted, the treaty has been listed as 'between' the contracting parties. 


\section{Names and titles of parties}

Because treaties are often a statement of, or claim to, what princes ruled over, as far as possible the titles of the contracting parties have been given as they are recorded in the text of the treaty. Specific explanations, where relevant, have been placed in endnotes. There is one significant exception: as is common also in Frankish capitularies of this period, the kings have no titles in the treaties, and are throughout the texts usually only referred to by their names and 'lord'. It is also worth noting that Lothar II was king of the so-called 'middle kingdom', which in the tenth century became known as Regnum Lotharii, i.e., kingdom of Lothar or Lotharingia. This designation has been used in square brackets in the list for convenience, even though anachronistic, in the same way the kingdoms of other Frankish rulers have also been indicated.

In some cases where a particular treaty has been concluded by a named representative, as given in the text, this has also been indicated in the list.

\section{Printed editions and translations}

Throughout I have tried to indicate every treaty where a translation or partial translation of the text exists. Such translations are in some cases rather old and not always entirely satisfactory, but these have been included to make the evidence accessible to nonspecialists and students. In some cases, there are several printed editions of the same treaty text. The aim has been to attempt to refer to the best edition of each text, but in cases where one edition has the text divided into clauses but the best text does not, both have been listed so that easy reference can be made to particular clauses in the main analysis.

\section{List of treaties}

Key: abp. (archbishop); c. (count); d. (duke); k. (king) 


\begin{tabular}{|c|c|c|}
\hline Name of Treaty & Printed edition & Parties and date \\
\hline II Ethelred & $\begin{array}{l}\text { Die Gesetze, I, 220-5. Translation in EHD, I, } \\
\quad 401-2 .\end{array}$ & $\begin{array}{l}994 \\
\text { Æthelred II, k. of the English } \\
\text { Olaf, Josteinn and Guthmund Steitason, leaders } \\
\text { of the army }\end{array}$ \\
\hline $\begin{array}{l}\text { Concordat of } \\
\text { Worms }\end{array}$ & $\begin{array}{l}\text { 'Pax Wormatiensis cum Calixto II', in MGH } \\
\text { Const. I, no. } 107 \text { (pp. 159-60) for promise of } \\
\text { Henry V; no. } 108 \text { (pp. 160-1) for promise of } \\
\text { Callixtus. A newer edition of Henry's promise } \\
\text { can be found with Die Urkunden Heinrichs } \\
\text { V. und der Königin Mathilde, eds. Matthias } \\
\text { Thiel and Alfred Gawlik, no. 240, available at } \\
\text { https://data.mgh.de/databases/ddhv/dhv_240. } \\
\text { htm }\end{array}$ & $\begin{array}{l}1122 \\
\text { Callixtus II, pope } \\
\text { Henry V, emperor }\end{array}$ \\
\hline $\begin{array}{l}\text { Division of the } \\
\text { Realm }\end{array}$ & 'Regni Divisio' in MGH Capit. II, 21-4. & $\begin{array}{l}831 \\
\text { Louis (the Pious), emperor } \\
\text { Pippin, k. of Aquitaine } \\
\text { Louis (the German), k. of Bavaria } \\
\text { Charles (the Bald), k. of Alemannia }\end{array}$ \\
\hline $\begin{array}{l}\text { Division of the } \\
\text { Realms }\end{array}$ & $\begin{array}{l}\text { 'Divisio regnorum' in MGH Capit. I, 126-30. } \\
\text { Translation in Charlemagne: Translated } \\
\text { Sources, 251-5. }\end{array}$ & $\begin{array}{l}806 \\
\text { Charles, emperor, k. of the Franks and of the } \\
\text { Lombards } \\
\text { Louis (the Pious), k. [of Aquitaine] } \\
\text { Pippin, k. [of Italy and Bavaria] } \\
\text { Charles, k. [of Frankia, Burgundy and Alemannia }\end{array}$ \\
\hline
\end{tabular}




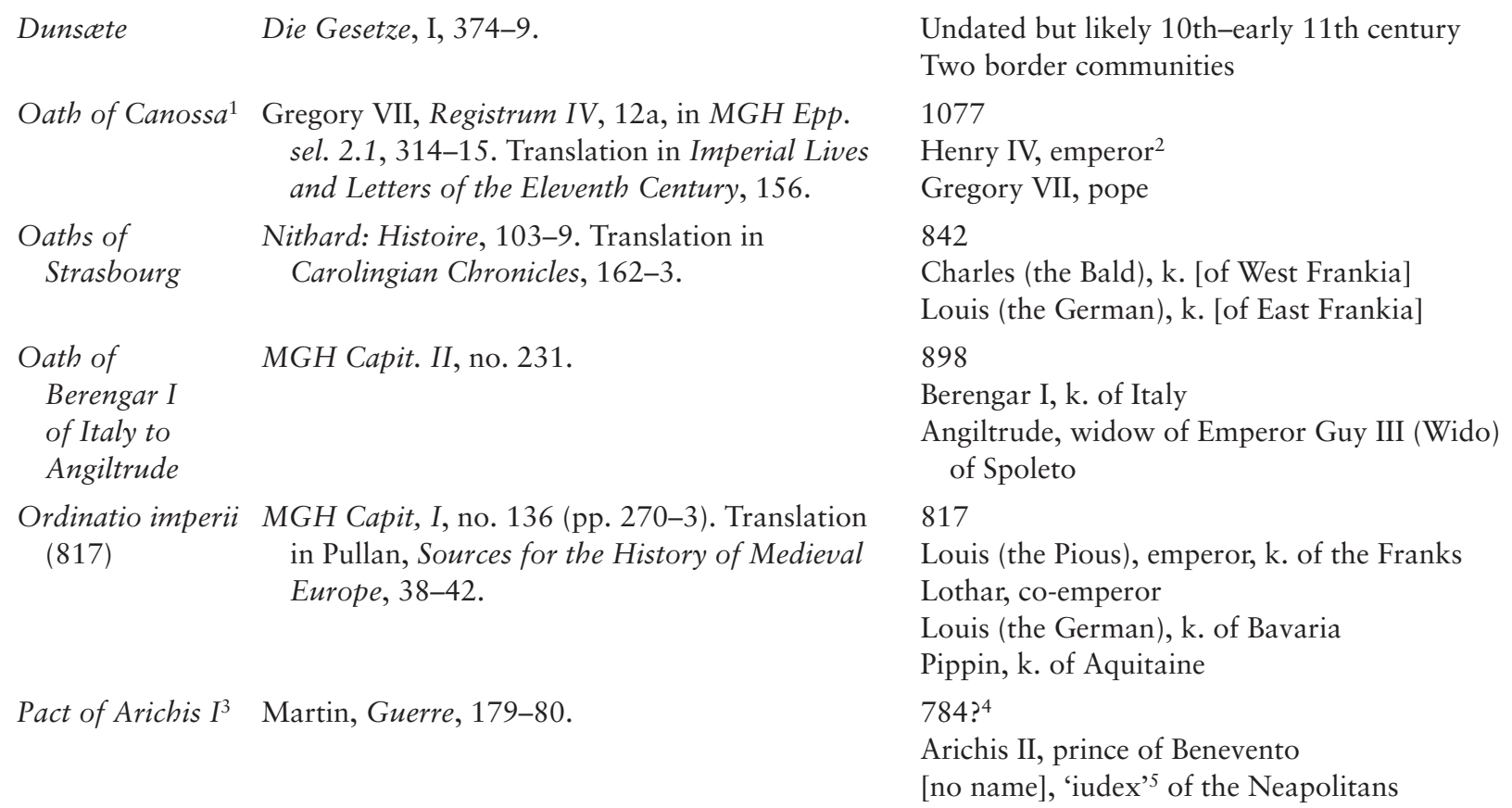

Oath of Canossa ${ }^{1}$ Gregory VII, Registrum IV, 12a, in MGH Epp. sel. 2.1, 314-15. Translation in Imperial Lives and Letters of the Eleventh Century, 156.
Oaths of Strasbourg
Nithard: Histoire, 103-9. Translation in Carolingian Chronicles, 162-3.

\section{Oath of \\ Berengar I \\ of Italy to \\ Angiltrude}

MGH Capit. II, no. 231.

Ordinatio imperii (817)

MGH Capit, I, no. 136 (pp. 270-3). Translation in Pullan, Sources for the History of Medieval Europe, 38-42.

Pact of Arichis $I^{3} \quad$ Martin, Guerre, 179-80.

Undated but likely 10 th-early 11 th century Two border communities

1077

Henry IV, emperor ${ }^{2}$

Gregory VII, pope

842

Charles (the Bald), k. [of West Frankia]

Louis (the German), k. [of East Frankia]

898

Berengar I, k. of Italy

Angiltrude, widow of Emperor Guy III (Wido) of Spoleto

817

Louis (the Pious), emperor, k. of the Franks

Lothar, co-emperor

Louis (the German), k. of Bavaria

Pippin, k. of Aquitaine

$784 ?^{4}$

Arichis II, prince of Benevento

[no name], 'iudex' ${ }^{5}$ of the Neapolitans

(continued) 


\begin{tabular}{|c|c|c|}
\hline Name of Treaty & Printed edition & Parties and date \\
\hline Pact of Arichis II & Martin, Guerre, 182-3. & $\begin{array}{l}784-7 ? \\
\text { Arichis II, prince of Benevento } \\
\text { Neapolitans }\end{array}$ \\
\hline $\begin{array}{l}\text { Pact between } \\
\text { Louis the } \\
\text { Pious and } \\
\text { Pope Paschal I }\end{array}$ & $\begin{array}{l}\text { 'Pactum Hludowici Pii cum Paschali pontifice', in } \\
\text { MGH Capit. I, no. } 172 \text { (pp. 352-5). }\end{array}$ & $\begin{array}{l}817 \\
\text { Louis (the Pious), emperor } \\
\text { Paschal I, pope }\end{array}$ \\
\hline $\begin{array}{l}\text { Pact between } \\
\text { Naples and } \\
\text { Benevento } \\
\text { (936) }\end{array}$ & Martin, Guerre, 217-19. & $\begin{array}{l}936 \\
\text { John III, d. of Naples } \\
\text { Landulf I, prince [of Benevento] } \\
\text { Atenulf II, prince [of Benevento] } \\
\text { Atenulf III, prince [of Benevento] }\end{array}$ \\
\hline $\begin{array}{l}\text { Pact between } \\
\text { Philip of } \\
\text { Swabia and } \\
\text { Philip II of } \\
\text { France }\end{array}$ & $\begin{array}{l}\text { MGH Const. II, 1-2. A partial English translation } \\
\text { is available in A Sourcebook for Mediceval } \\
\text { History, eds. Oliver J. Thatcher and Edgar } \\
\text { Holmes McNeal (New York, 1905), 227-8. }\end{array}$ & $\begin{array}{l}1198 \\
\text { Philip II, k. of the Franks } \\
\text { Philip [of Swabia], k. of the Romans }\end{array}$ \\
\hline Pactum Sicardi & $\begin{array}{l}\text { MGH LL, iv, ed. G. H. Pertz (Hanover, 1868), } \\
\text { 216-21.6 See also revisions of this text in } \\
\text { Martin, Guerre, 185-99. A partial English } \\
\text { translation is available in Medieval Trade in the } \\
\text { Mediterranean World, 33-5. }\end{array}$ & $\begin{array}{l}836 \\
\text { Sicard, p. of the Lombard people } \\
\text { Andrea II, magister militum }{ }^{7} \text { of Naples } \\
\text { John, bishop-elect of Naples }\end{array}$ \\
\hline
\end{tabular}




\section{Partition of Benevento

\section{Peace of \\ Constance}

(1183)

Treaty of Aachen

$$
\begin{aligned}
& \text { Treaty of } \\
& \text { Acre }^{9}(1124)
\end{aligned}
$$

Treaty of Acre A $^{11}$ (1190)
DD FI, iv, no. 848 (pp. 68-77). A partial English translation is available in Medieval Italy: Texts in Translation, eds. Katherine L. Jansen et al. (Philadelphia, 2009), 61-3.

'Pactiones Aquenses' in MGH Capit. II, 192. Translation in The Annals of St-Bertin, 166.

UHSRV, I, no. 40 (pp. 79-89, text pp. 84-9). The confirmation of 1125 is available in same volume no. 41 (pp. 90-4). Translation in A History of Deeds Done beyond the Sea. Volume 1, ed. Emily Atwater Babcock and A.C. Krey (New York, 1943), 552-6.

LIRG, vol. 1/2, no. 332 (pp. 183-9). Translation in Hall, Caffaro, 140-2.
$848 \times 849$

Radelchis I, prince [of Benevento]

Sikenolf, prince of Salerno

1183

Frederick I, emperor

Henry VI, k. of the Romans (son of the emperor)

The cities of the Lombard League

870

Charles (the Bald), k. [of West Frankia]

Louis (the German), k. [of East Frankia]

1124

Domenico Michiele, d. of the Venetians

Baldwin II, k. of Jerusalem, through his representatives Warmund, patriarch of Jerusalem; William de Bury, constable of the king; and Payens, chancellor of the king ${ }^{10}$

1190

Genoa, represented by Guidone Spinola Guy, k. of the Latins in Jerusalem ${ }^{12}$

Sibylla, queen 


\begin{tabular}{|c|c|c|}
\hline Name of Treaty & Printed edition & Parties and date \\
\hline $\begin{array}{l}\text { Treaty of } \\
\text { Adrianople }\end{array}$ & $\begin{array}{l}\text { Historia de expeditione, 64-6. Translation in } \\
\text { CFB, 90-2. }\end{array}$ & $\begin{array}{l}1190 \\
\text { Frederick I, emperor } \\
\text { Isaac II, emperor }\end{array}$ \\
\hline Treaty of Agreda & $\begin{array}{l}\text { González, El reino de Castilla, no. } 449 \\
\quad \text { (pp. 770-1) }\end{array}$ & $\begin{array}{l}1186 \\
\text { Alfonso VIII, k. of Castile } \\
\text { Alfonso II, k. of Aragon }\end{array}$ \\
\hline Treaty of Anagni & $\begin{array}{l}\text { DD FI, iii, no. } 658 \text { (pp. 161-5). A partial English } \\
\text { translation is available in A Sourcebook for } \\
\text { Mediceval History, 197-9. }\end{array}$ & $\begin{array}{l}1176 \\
\text { Frederick I, emperor, through his representatives } \\
\text { Alexander III, pope, through his representatives }\end{array}$ \\
\hline Treaty of Andeli & EMDP, ii, no. 243 (pp. 466-7). & $\begin{array}{l}1197 \\
\text { Richard I, k. of England } \\
\text { Baldwin IX, c. of Flanders }\end{array}$ \\
\hline $\begin{array}{l}\text { Treaty of } \\
\qquad \begin{array}{l}\text { Antioch } \\
\text { (1098) }\end{array}\end{array}$ & $\begin{array}{l}\text { CDRG, I, nos. 7-8 (pp. 11-13). The first } \\
\text { document is Bohemond's grant of privileges } \\
\text { in Antioch, while the second is the Genoese } \\
\text { obligations. Translation in Hall, Caffaro, } \\
169-70 .\end{array}$ & $\begin{array}{l}1098 \\
\text { Bohemond I, lord } \\
\text { Genoa }\end{array}$ \\
\hline $\begin{array}{l}\text { Treaty of Antioch } \\
\text { (1101) }\end{array}$ & $\begin{array}{l}\text { CDRG, I, no. } 12 \text { (pp. 16-18). Translation in Hall, } \\
\text { Caffaro, } 170 .\end{array}$ & $\begin{array}{l}1101 \\
\text { Tancred }^{15} \\
\text { Genoa }\end{array}$ \\
\hline $\begin{array}{l}\text { Treaty of } \\
\qquad \begin{array}{l}\text { Antioch } \\
\text { (1127) }\end{array}\end{array}$ & $\begin{array}{l}\text { LIRG, vol. } 1 / 2, \text { no. } 337 \text { (pp. 152-4). Translation } \\
\text { in Hall, Caffaro, 171-2. }\end{array}$ & $\begin{array}{l}1127 \\
\text { Bohemond II, prince of Antioch } \\
\text { Genoa }\end{array}$ \\
\hline
\end{tabular}


Treaty of Antioch UHSRV, I, no. 61 (pp. 148-50)

(1167)

Treaty of Antioch LIRG, vol. 1/2, no. 340 (pp. 157-60). Translation $(1169)^{18}$ in Hall, Caffaro, 172-3.

Treaty of Ardara

LIRG, vol. 1/2, no. 409 (pp. 377-9). For the Genoese ratification, see same volume, no. 410 (pp. 380-2).

Treaty of Arles ${ }^{20}$

$C D R G$, ii, no. 7 (pp. 16-17); LIRG, vol. 1/2, no. 366 (pp. 256-7).

\section{Treaty of Artlenburg}

Treaty of Azay

\section{Urkunden Heinrichs des Löwen, part I, ed.} K. Jordan (Leipzig, 1941; repr. 1957), no. 48 (pp. 68-70)

Howden, Gesta, ii, 70-1.
1167

Bohemond II, prince of Antioch [not specified], d. of the Venetians ${ }^{17}$

1169

Bohemond III, prince of Antioch

Genoa

1191

Constantine, 'iudex'19 of Torres

Genoa

1165

Ramon Berenguer II, c. of Provence

Genoa

1161

Henry the Lion, d. of Saxony

The Gotlanders

1189

Henry II, k. of England

Philip II, k. of France 


\begin{tabular}{|c|c|c|}
\hline Name of Treaty & Printed edition & Parties and date \\
\hline $\begin{array}{l}\text { Treaty of } \\
\text { Bamberg }\end{array}$ & $\begin{array}{l}\text { 'Pactum cum Benedicto VIII', in MGH Const. I, } \\
\text { no. } 33 \text { (pp. 65-70). }\end{array}$ & $\begin{array}{l}1020 \\
\text { Henry II, emperor } \\
\text { Benedict VIII, pope }\end{array}$ \\
\hline $\begin{array}{l}\text { Treaty of the } \\
\text { Basilica of } \\
\text { Cosmas and } \\
\text { Damian }^{21}\end{array}$ & $\begin{array}{l}\text { CDRG, I, no. } 31 \text { (pp. 38-40). Translation in Hall, } \\
\text { Caffaro, 103-5. }\end{array}$ & $\begin{array}{l}1120 \\
\text { Genoa } \\
\text { The 'fideles' of Pope Calixtus II }\end{array}$ \\
\hline $\begin{array}{l}\text { Treaty of } \\
\text { Benevento } \\
(1073)\end{array}$ & $\begin{array}{l}\text { Gregory VII, Registrum I, 18a, in MGH Epp. } \\
\text { sel. 2.1, 30-1. Translation in The Register of } \\
\text { Gregory VII, no. 1.18a (pp. 20-1). }\end{array}$ & $\begin{array}{l}1073 \\
\text { Gregory VII, pope } \\
\text { Landulf VI, prince of Benevento }\end{array}$ \\
\hline $\begin{array}{l}\text { Treaty of } \\
\text { Benevento } \\
(1156)\end{array}$ & $\begin{array}{l}\text { MGH Const. I, no. } 413 \text { (pp. 588-90). Translation } \\
\text { in The History of the Tyrants of Sicily by } \\
\text { "Hugo Falcandus", 1154-69, tr. G.A. Loud } \\
\text { and Thomas Wiedemann (Manchester, 1998), } \\
\text { 248-52. }\end{array}$ & $\begin{array}{l}1156 \\
\text { William I, k. of Sicily } \\
\text { Adrian IV, pope }\end{array}$ \\
\hline $\begin{array}{l}\text { Treaty of Bonn } \\
\text { (921) }\end{array}$ & $\begin{array}{l}\text { 'Pactum cum Karolo Rege Franciae Occidentalis', } \\
\text { in MGH Const. I, 1-2. There is a partial } \\
\text { English translation in Grewe, The Epochs of } \\
\text { International Law, } 77 .\end{array}$ & $\begin{array}{l}921 \\
\text { Charles the Simple, k. of the West Franks } \\
\text { Henry I, k. of the East Franks }\end{array}$ \\
\hline
\end{tabular}



Treaty of Burgo
San Genesio

Treaty of
Canterbury

Treaty of Capua

Treaty of Castel San Giovanni

Treaty of Ceprano

\section{Treaty of} Constance (1153)
MGH Const. I, no. 214 (pp. 302-4); for the oath of the consuls of Lucca, see DD FI, ii, no. 375 (pp. 239-41).

Anglo-Scottish Relations 1174-1328, no. 2 (pp. 6-8).

Gregory VII, Registrum I, 21a, in MGH Epp. sel. 2.1, 35-6. Translation in The Register of Gregory VII, no. 1.21a (pp. 25-6).

'Pactum cum Venetis', in MGH Const. I, no. 378 (526-30).

Le Liber Censuum, I, 422.

DD FI, i, nos. 51-2 (pp. 85-9).

Translation in A Sourcebook for Mediceval History, 179-80.
1162

Frederick I, emperor, through his representative Rainald von Dassel, abp. of Cologne and arch-chancellor

\section{Lucca}

1189

Richard I, k. of the English

William I, k. of Scotland

1073

Gregory VII, pope

Richard, prince of Capua

1197

Henry VI, emperor and k. of Sicily

Enrico Dandolo, d. of Venetians

1080

Robert Guiscard, d. of Apulia, Calabria and Sicily Gregory VII, pope

1153

Frederick I, k. of the Romans

Eugene III, pope 


\begin{tabular}{|c|c|c|}
\hline Name of Treaty & Printed edition & Parties and date \\
\hline $\begin{array}{l}\text { Treaty of } \\
\text { Constantinople } \\
\text { (911) }\end{array}$ & $R P C, 65-8$ & $\begin{array}{l}911 \\
\text { Oleg, Grand Prince of Rus' } \\
\text { Leo VI, emperor } \\
\text { Alexander, co-emperor } \\
\text { Constantine, co-emperor }\end{array}$ \\
\hline $\begin{array}{l}\text { Treaty of } \\
\text { Constantinople } \\
\text { (944) }\end{array}$ & $R P C, 73-7$. & $\begin{array}{l}944 \\
\text { Igor, Grand Prince of Rus' } \\
\text { Romanos I, emperor } \\
\text { Constantine, co-emperor } \\
\text { Stephen, co-emperor }\end{array}$ \\
\hline $\begin{array}{l}\text { Treaty of } \\
\text { Constantinople } \\
\text { (992) }\end{array}$ & $\begin{array}{l}\text { I trattati con Bisanzio, 992-1198, eds. M. Pozza } \\
\text { and G. Ravegnani (Venice, 1993), no. } 1 \\
\quad \text { (pp. 21-5); UHSRV, no. } 17 \text { (pp. 36-9). }\end{array}$ & $\begin{array}{l}992 \\
\text { Basil II, co-emperor } \\
\text { Constantine VIII, co-emperor } \\
\text { Peter Orseolo II, d. of Venetians }\end{array}$ \\
\hline $\begin{array}{l}\text { Treaty of } \\
\text { Constantinople } \\
(1169)\end{array}$ & $\begin{array}{l}\text { LIRG, vol. 1/2, no. } 352 \text { (pp. 183-9). Translation } \\
\text { in Hall, Caffaro, 204-7. }\end{array}$ & $\begin{array}{l}1169 \\
\text { Genoa } \\
\text { Manuel Komnenos, emperor }\end{array}$ \\
\hline $\begin{array}{l}\text { Treaty of } \\
\text { Correggio } \\
\text { Verde }^{23}\end{array}$ & $\begin{array}{l}\text { Die Urkunden Lothars III. und der Kaiserin } \\
\text { Richenza, ed. E. von Ottenthal and H. Hirsch } \\
\text { (Berlin, 1927), no. } 97 \text { (pp. 151-6). }\end{array}$ & $\begin{array}{l}1136 \\
\text { Lothar III, emperor } \\
\text { Pietro Polani, d. of the Venetians }\end{array}$ \\
\hline $\begin{array}{l}\text { Treaty of } \\
\text { Cremona }\end{array}$ & CDRG, II, no. 111 (pp. 243-5). & $\begin{array}{l}1177 \\
\text { Venice } \\
\text { Genoa }\end{array}$ \\
\hline
\end{tabular}




\begin{tabular}{|c|c|c|}
\hline Treaty of Devol & $\begin{array}{l}\text { Anne Comnène, Alexiade, } 4 \text { vols., ed. and tr. } \\
\text { Bernard Leib (Paris: 1937-76), III, 125-39 } \\
\text { (bk. XIII, ch. 12). Translation in The Alexiad, } \\
\text { 424-34. }\end{array}$ & $\begin{array}{l}1108 \\
\text { Alexios I Komnenos, emperor } \\
\text { Bohemond I, prince of Antioch }\end{array}$ \\
\hline $\begin{array}{l}\text { Treaty of Dover } \\
\quad(1101)\end{array}$ & $\begin{array}{l}\text { Dip. Docs, no. } 1 \text { (pp. 1-4). Translation in E. van } \\
\text { Houts, 'The Anglo-Flemish treaty of 1101', } \\
\text { ANS, } 21 \text { (1998), 169-74. }\end{array}$ & $\begin{array}{l}1101 \\
\text { Henry I, k. of the English } \\
\text { Robert II, c. of Flanders }\end{array}$ \\
\hline $\begin{array}{l}\text { Treaty of Dover } \\
\quad(1110)\end{array}$ & Dip. Docs, no. 2 (pp. 5-7). & $\begin{array}{l}1110 \\
\text { Henry I, k. of the English } \\
\text { Robert II, c. of Flanders }\end{array}$ \\
\hline $\begin{array}{l}\text { Treaty of Dover } \\
\quad(1163)\end{array}$ & $\begin{array}{l}\text { Dip. Docs, no. } 3 \text { (pp. 8-12). Translation in } \\
\text { Oksanen, Flanders and the Anglo-Norman } \\
\text { World, 264-9. }\end{array}$ & $\begin{array}{l}1163 \\
\text { Henry II, k. of the English } \\
\text { Thierry, c. of Flanders } \\
\text { Philip, c. and heir [to Flanders] }\end{array}$ \\
\hline Treaty of Falaise & Anglo-Scottish Relations 1174-1328, 2-11. & $\begin{array}{l}1174 \\
\text { Henry II, k. of England } \\
\text { William I (the Lion), k. of Scots }\end{array}$ \\
\hline $\begin{array}{l}\text { Treaty of Fitero } \\
\text { (1167) }\end{array}$ & Howden, Gesta, i, 149-50. & $\begin{array}{l}1167 \\
\text { Alfonso VIII, k. of Castile } \\
\text { Sancho VI, k. of Navarre }\end{array}$ \\
\hline
\end{tabular}




\begin{tabular}{|c|c|c|}
\hline Name of Treaty & Printed edition & Parties and date \\
\hline Treaty of Fouron & $\begin{array}{l}\text { Hludowici iunioris et Hludowici Balbi conventio } \\
\text { Furonensis, in MGH Capit. II, no. } 246 \\
\text { (pp. 168-70). Translation in The Annals of St- } \\
\text { Bertin, 213-15. }\end{array}$ & $\begin{array}{l}878 \\
\text { Louis (the Stammerer), } \mathrm{k} . \\
\text { Louis (the Younger), } \mathrm{k} .\end{array}$ \\
\hline Treaty of Fulda & DD FI, iii, no. 602 (pp. 86-7). & $\begin{array}{l}1173 \\
\text { Frederick I, emperor } \\
\text { Philip, c. of Flanders }\end{array}$ \\
\hline Treaty of Gaeta & Martin, Guerre, no. 6 (pp. 222-3). & $\begin{array}{l}1029 \\
\text { Sergius IV, d. of Naples and 'magister militum' } \\
\text { John V, consul and d. of Gaeta } \\
\text { Emilia, duchess of Gaeta } \\
\text { Sicelgaite } \\
\text { The people of Gaeta } \\
\text { The }\end{array}$ \\
\hline $\begin{array}{l}\text { Treaty of } \\
\text { Galliate }^{27}\end{array}$ & DD FI, I, no. 94 (pp. 156-60). & $\begin{array}{l}1154 \\
\text { Frederick I, k. of the Romans } \\
\text { Domenico Morosini, d. of the Venetians }\end{array}$ \\
\hline $\begin{array}{l}\text { Treaty of Genoa } \\
\quad I(1146)\end{array}$ & $\begin{array}{l}\text { LIRG, vol. 1/6, nos. } 932 \text { (pp. 3-6). For the } \\
\text { Genoese obligations, see same volume no. } 933 \\
\text { (pp. 6-7). Translation in Hall, Caffaro, 179-82. }\end{array}$ & $\begin{array}{l}1146 \\
\text { Genoa } \\
\text { Alfonso VII, emperor of Spain } 28\end{array}$ \\
\hline $\begin{array}{l}\text { Treaty of Genoa } \\
\quad I I(1146)\end{array}$ & $\begin{array}{l}\text { LIRG, vol. } 1 / 6 \text {, no. } 934 \text { (pp. 8-11). Translation } \\
\text { in Hall, Caffaro, } 182-3 \text {. For the obligations of } \\
\text { Ramon Berenguer, see LIRG, vol. } 1 / 2 \text {, no. } 297 \\
\text { (pp. 62-9). }\end{array}$ & $\begin{array}{l}1146 \\
\text { Genoa } \\
\text { Ramon Berenguer IV, c. of Barcelona }\end{array}$ \\
\hline
\end{tabular}


Treaty of Genoa (1164)

\section{Treaty of Genoa} (1165)

Treaty of Genoa (1168)

Treaty of Genoa (1172)

Treaty of Genoa (1174)

Treaty of Genoa (1186)

Treaty of Genoa I (1190)
LIRG, vol. 1/2, no. 382 (pp. 317-22).

CDRG, II, nos. 8-9 (pp. 17-22; 22-7). The ratifications are published as nos. 12-13 in same volume (pp. 29-39).

LIRG, vol. 1/2, no. 388 (pp. 331-3).

LIRG, vol. 1/2, no. 385 (pp. 327-31).

LIRG, vol. 1/2, no. 362-3 (pp. 231-44).

LIRG, vol. 1/2, no. 407 (pp. 373-5). For Genoese obligations, see same volume no. 408 (pp. 375-7).

LIRG, vol. 1/6, no. 935 (pp. 11-14). The Genoese obligations are available in $C D R G$, ii, no. 192 (pp. 366-8). Translation of the French obligations in Hall, Caffaro, 218-20.
1164

Genoa

Barisone II, k. of Sardinia

1165

Genoa

Rome

1168

Genoa

Barisone II, k. of Sardinia

1172

Genoa

Barisone II, k. of Arborea

1174

Raymond V, c. of Toulouse

Genoa

1186

Barisone II, 'iudex' of Torres

Genoa

1190

Philip II, k. of the Franks, through his representative Hugh, d. of Burgundy Genoa 


\begin{tabular}{|c|c|c|}
\hline Name of Treaty & Printed edition & Parties and date \\
\hline $\begin{array}{l}\text { Treaty of Genoa } \\
\text { II (1190) }\end{array}$ & $\begin{array}{l}\text { LIRG, vol. 1/2, no. } 353 \text { (pp. 189-92). Translation } \\
\text { in Hall, Caffaro, 221-2. }\end{array}$ & $\begin{array}{l}1190 \\
\text { Philip II, k. of the Franks } \\
\text { Genoa }\end{array}$ \\
\hline $\begin{array}{l}\text { Treaty of Genoa } \\
\qquad(1192)\end{array}$ & CDRG, III, no. 11 (pp. 25-6). & $\begin{array}{l}1192 \\
\text { Genoa } \\
\text { Alessandria }\end{array}$ \\
\hline $\begin{array}{l}\text { Treaty of } \\
\qquad \text { Genoa }^{29} \\
(1198)\end{array}$ & LIRG, vol. 1/2, no. 395 (pp. 347-50). & $\begin{array}{l}1198 \\
\text { Hugh de Bassio, son of Hugh de Bassio }{ }^{30} \\
\text { Genoa, represented by Alberto de Mandello }\end{array}$ \\
\hline $\begin{array}{l}\text { Treaty of } \\
\text { Gerberoy }\end{array}$ & Gerald of Wales, Instruction for a Ruler, 500-3. & $\begin{array}{l}1182 \\
\text { Philip II, k. of France } \\
\text { Philip d'Alsace, c. of Flanders }\end{array}$ \\
\hline $\begin{array}{l}\text { Treaty of Gisors } \\
\qquad(1160)\end{array}$ & $\begin{array}{l}\text { Recueil des actes de Henri II, roi d'Angleterre et } \\
\text { duc de Normandie concernant les provinces } \\
\text { françaises et les affaires de France, } 2 \text { vols., ed. } \\
\text { L. Delisle, revised by E. Berger (Paris, 1916), I, } \\
\text { no. } 141 \text { (pp. 251-3); L. Landon, The Itinerary } \\
\text { of King Richard I (London, 1935), 221-2. }\end{array}$ & $\begin{array}{l}1160 \\
\text { Louis VII, k. of France } \\
\text { Henry II, k. of England }\end{array}$ \\
\hline $\begin{array}{l}\text { Treaty of Gisors } \\
\quad(1180)\end{array}$ & $\begin{array}{l}\text { Rec. des actes de Philippe Auguste, i, no. } 7 \text { (with } \\
\text { division into clauses); Howden, Gesta, I, 247-9; } \\
\text { Howden, Chronica, ii, 198-9. Translation in } \\
\text { The Annals of Roger de Hoveden, } 2 \text { vols., ed. } \\
\text { H.T. Riley (London, 1853), i, 521-3. }\end{array}$ & $\begin{array}{l}1180 \\
\text { Philip II, k. of the Franks } \\
\text { Henry II, k. of the English }\end{array}$ \\
\hline
\end{tabular}




\begin{tabular}{|c|c|c|}
\hline $\begin{array}{l}\text { Treaty of Le } \\
\text { Goulet }\end{array}$ & $\begin{array}{l}\text { EMDP, II, no. } 288 \text { (pp. 615-17); Howden, } \\
\text { Chronica, iv, 148-51. Translation in The Annals } \\
\text { of Roger de Hoveden, ii, 508-12. }\end{array}$ & $\begin{array}{l}1200 \\
\text { John, k. of England } \\
\text { Philip II, k. of the Franks }\end{array}$ \\
\hline $\begin{array}{l}\text { Treaty of } \\
\text { Gravina }\end{array}$ & $\begin{array}{l}\text { 'Tancredi regis pactum cum Coelestino III', in } \\
\text { MGH Const. I, no. } 417 \text { (pp. 593-4). The oaths } \\
\text { are in same volume, nos. } 416,418 \text { (pp. 592-3, } \\
595) .\end{array}$ & $\begin{array}{l}1192 \\
\text { Tancred, k. of Sicily } \\
\text { Celestine III, pope }\end{array}$ \\
\hline $\begin{array}{l}\text { Treaty of } \\
\text { Grosseto }\end{array}$ & CDRG, I, no. 64 (pp. 76-7). & $\begin{array}{l}1133 \\
\text { Pope Innocent II (arbiter) } \\
\text { Genoa } \\
\text { Pisa }\end{array}$ \\
\hline Treaty of Hyères & LIRG, vol. 1/2, nos. 396 (pp. 350-4). & $\begin{array}{l}1186 \\
\text { Arenburg, queen of Arborea } \\
\text { Genoa }\end{array}$ \\
\hline $\begin{array}{l}\text { Treaty of Ivry } \\
\text { (1177) }\end{array}$ & $\begin{array}{l}\text { Howden, Gesta, i, 191-6; Howden, Chronica, } \\
\text { ii, 144-6. Translation in The Annals of Roger } \\
\text { de Hoveden, I, 464-6. A version, based on the } \\
\text { French exemplar, is also available in Gerald of } \\
\text { Wales, Instruction for a Ruler, 460-7. }\end{array}$ & $\begin{array}{l}1177 \\
\text { Henry II, k. of England } \\
\text { Louis VII, k. of Franks }\end{array}$ \\
\hline $\begin{array}{l}\text { Treaty of } \\
\quad \text { Jarnègues }\end{array}$ & $\begin{array}{l}\text { Actes concernant les vicomtes de Marseille et leur } \\
\text { descendants, ed. H. De Gérin-Ricard (Monaco, } \\
\text { 1926), no. } 288 \text { (pp. 81-3). }\end{array}$ & $\begin{array}{l}1190 \\
\text { Alfonso II, k. of Aragon } \\
\text { Raymond V, c. of Toulouse }\end{array}$ \\
\hline
\end{tabular}




\begin{tabular}{|c|c|c|}
\hline Name of Treaty & Printed edition & Parties and date \\
\hline $\begin{array}{l}\text { Treaty of } \\
\text { Justinopolis } 34 \\
\text { (932) }\end{array}$ & UHSRV, I, no. 10 (pp. 5-10). & $\begin{array}{l}932 \\
\text { Peter Candiano, d. of Venetians } \\
\text { Justinopolis }\end{array}$ \\
\hline $\begin{array}{l}\text { Treaty of } \\
\text { Justinopolis } \\
\text { (977) }\end{array}$ & UHSRV, I, no. 15 (pp. 31-5). & $\begin{array}{l}977 \\
\text { Peter Orseolo I, d. of Venetians } \\
\text { Sicard, c. of Justinopolis }\end{array}$ \\
\hline $\begin{array}{l}\text { Treaty of } \\
\text { Koblenz }\end{array}$ & $\begin{array}{l}\text { 'Hludowici, Karoli et Lotharii II. Conventus } \\
\text { apud Confluentes', in MGH Capit. II, no. } 242 \\
\text { (pp. 152-8). For translation of the oath of } \\
\text { Louis, see The Annals of Fulda, } 47 .\end{array}$ & $\begin{array}{l}860 \\
\text { Charles (the Bald), k. [of West Frankia] } \\
\text { Louis (the German), k. [of East Frankia] } \\
\text { Lothar II, k. [of Lotharingia] }\end{array}$ \\
\hline Treaty of Lerici ${ }^{35}$ & CDRG, II, no. 14 (pp. 40-7). & $\begin{array}{l}1166 \\
\text { Genoa } \\
\text { Lucca }\end{array}$ \\
\hline Treaty of Liège & $\begin{array}{l}\text { 'Hlotharii et Karoli Conventus Leodii Habitus', in } \\
\text { MGH Capit. II, no. } 207 \text { (pp. 76-8). }\end{array}$ & $\begin{array}{l}854 \\
\text { Lothar I, emperor } \\
\text { Charles (the Bald), k. [of West Frankia] }\end{array}$ \\
\hline Treaty of Lodi & $A C M$, nos. 53-4 (76-81). & $\begin{array}{l}1167 \\
\text { Lodi } \\
\text { Milan } \\
\text { Bergamo } \\
\text { Cremona } \\
\text { Brescia } \\
\text { Mantua }\end{array}$ \\
\hline
\end{tabular}




\begin{tabular}{|c|c|c|}
\hline $\begin{array}{l}\text { Treaty of } \\
\text { Logroño } \\
\text { (1176) }\end{array}$ & $\begin{array}{l}\text { Howden, Gesta, i, 140-3; Howden, Chronica, ii, } \\
\text { 122-4. Translation in The Annals of Roger de } \\
\text { Hoveden, i, 441-4. }\end{array}$ & $\begin{array}{l}1176 \\
\text { Alfonso VIII, k. of Castile } \\
\text { Sancho VI, k. of Navarre }\end{array}$ \\
\hline $\begin{array}{l}\text { Treaty of } \\
\text { Logroño } \\
\text { (1179) }\end{array}$ & $\begin{array}{l}\text { González, El reino de Castilla, no. } 321 \\
\text { (pp. 532-7). }\end{array}$ & $\begin{array}{l}1179 \\
\text { Alfonso VIII, k. of Castile } \\
\text { Sancho VI, k. of Navarre }\end{array}$ \\
\hline Treaty of London & $\begin{array}{l}\text { Howden, Gesta, I, 151-4; Howden, Chronica, ii, } \\
\text { 129-31. Translation in The Annals of Roger de } \\
\text { Hoveden, i, 449-51. }\end{array}$ & $\begin{array}{l}1177 \\
\text { Henry, k. of England (arbiter) } \\
\text { Alfonso VIII, k. of Castile } \\
\text { Sancho VI, k. of Navarre }\end{array}$ \\
\hline $\begin{array}{l}\text { Treaty of } \\
\text { Louviers }^{36}\end{array}$ & $\begin{array}{l}\text { Dip. Docs, no. } 6 \text { (pp. 16-18). Published with } \\
\text { divisions into clauses in Rec. des actes de } \\
\text { Philippe Auguste, II, no. } 517 \text { (pp. 53-7). }\end{array}$ & $\begin{array}{l}1196 \\
\text { Richard I, k. of England } \\
\text { Philip II, k. of the Franks }\end{array}$ \\
\hline Treaty of $\mathrm{Lucca}^{37}$ & $\begin{array}{l}C D R G \text {, II, no. } 174 \text { (pp. 334-9). For the oaths } \\
\text { agreeing to the arbitration, see same volume } \\
\text { no. } 172 \text { (pp. } 321-32 \text { ). The pope's order to } \\
\text { adhere to decision is no. } 173 \text { (p. } 333 \text { ). }\end{array}$ & $\begin{array}{l}1188 \\
\text { Clement III, pope (arbiter), through his papal } \\
\text { legates the cardinal priests Peter of Santa Cecilia } \\
\text { and Sifrid of Santa Maria in Via Lata } \\
\text { Genoa } \\
\text { Pisa }\end{array}$ \\
\hline
\end{tabular}




\begin{tabular}{|c|c|c|}
\hline Name of Treaty & Printed edition & Parties and date \\
\hline $\begin{array}{l}\text { Treaty of } \\
\text { Mallorca } \\
\text { (1181) }\end{array}$ & $\begin{array}{l}\text { Latin text: CDRG, II, no. } 133 \text { (pp. 271-3). } \\
\text { For French translation of Arabic text, see } \\
\text { Mas Latrie, Traités de paix, 109-113; for } \\
\text { Italian translation of Arabic text, see Frédéric } \\
\text { Bauden, 'Due trattati di pace conclusi nel } \\
\text { dodicesimo secolo tra i Banū Gāniya, signori } \\
\text { delle isole Baleari, e il commune di Genova', in } \\
\text { Documentos y manuscritos árabes del occidente } \\
\text { musulmán medieval, ed. Nuria Martínez de } \\
\text { Castilla (Madrid, 2010), 51-6. }\end{array}$ & $\begin{array}{l}1181 \\
\text { Genoa, through its representative Rodoan } \\
\text { de Mauro } \\
\text { Ishak-ibn-Mohammed, governor ('Alfachinus') of } \\
\text { the Balearic islands }\end{array}$ \\
\hline $\begin{array}{l}\text { Treaty of } \\
\qquad \text { Mallorca } \\
\text { (1188) }\end{array}$ & $\begin{array}{l}\text { Latin text: } C D R G \text {, II, no. } 177 \text { (pp. } 341-4 \text { ). } \\
\text { For Italian translation of the Arabic text, see } \\
\text { Bauden, 'Due trattati di pace', } 70-4 \text {. }\end{array}$ & $\begin{array}{l}1188 \\
\text { Genoa, through its representative Nicholas } \\
\text { Lecanozze } \\
\text { Abu Mohammed Abd-Allah, k. of Mallorca }{ }^{38}\end{array}$ \\
\hline Treaty of Mantes & $\begin{array}{l}\text { Howden, Chronica, iii, 217-20; EMDP, II, } \\
\text { no. } 287 \text { (pp. 613-15). Translation in The } \\
\text { Annals of Roger de Hoveden, ii, 298-301. }\end{array}$ & $\begin{array}{l}1193 \\
\text { Richard I, k. of England, through his } \\
\text { representatives } \\
\text { Philip II, k. of France }\end{array}$ \\
\hline $\begin{array}{l}\text { Treaty of } \\
\quad \text { Meerssen (847) }\end{array}$ & $\begin{array}{l}\text { 'Hlotharii, Hludowici et Karoli conventus apud } \\
\text { Marsnam primus', in MGH Capit. II, no. } 204 \\
\text { (pp. 68-71). For a partial English translation of } \\
\text { the 'announcement' of Charles the Bald, see A } \\
\text { Sourcebook for Mediceval History, 360-1. }\end{array}$ & $\begin{array}{l}847 \\
\text { Lothar, [emperor] } \\
\text { Louis (the German), [k. of East Frankia] } \\
\text { Charles (the Bald), [k. of West Frankia] }\end{array}$ \\
\hline
\end{tabular}




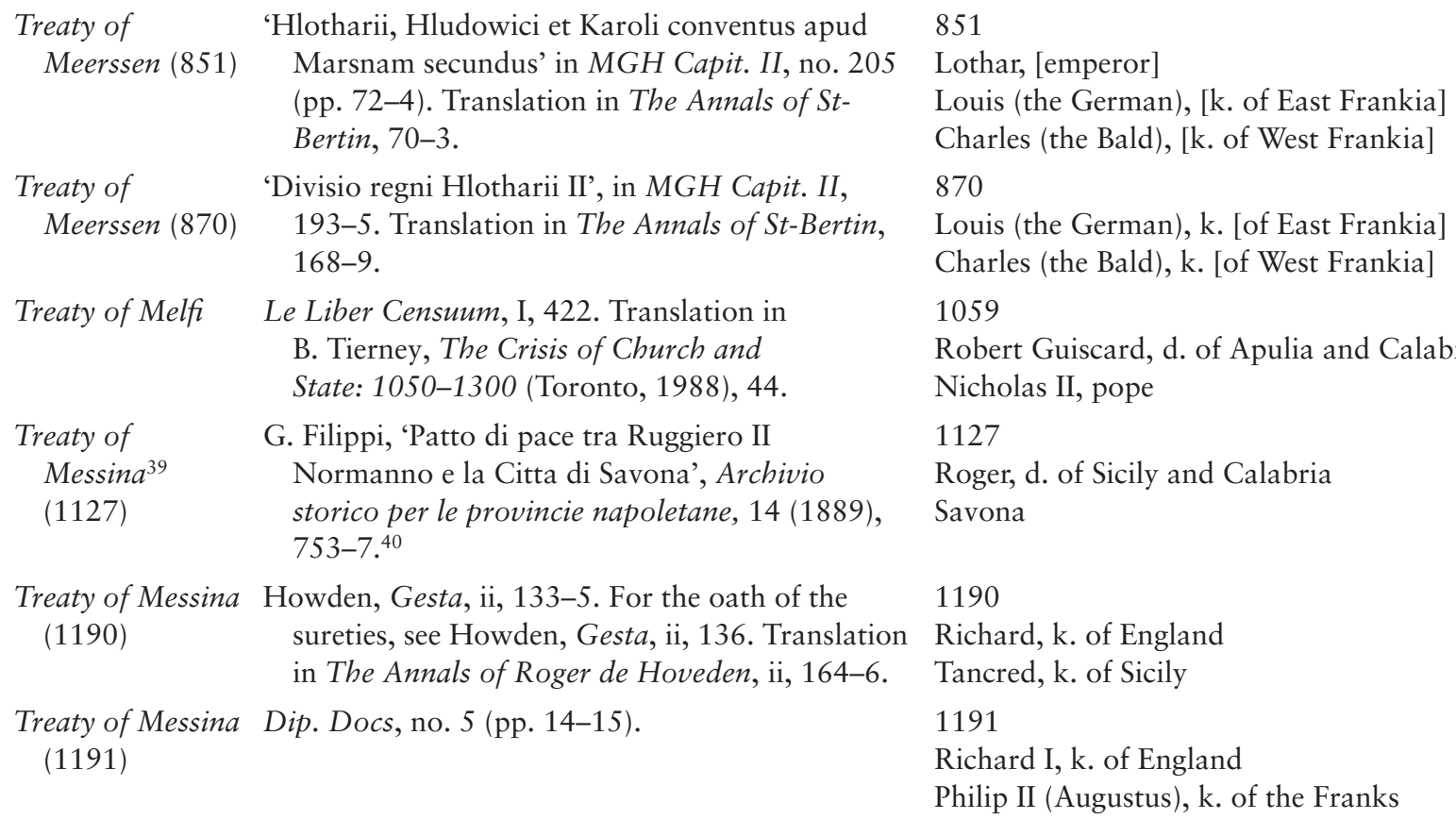

Treaty of Melfi Le Liber Censuum, I, 422. Translation in B. Tierney, The Crisis of Church and State: 1050-1300 (Toronto, 1988), 44.

Treaty of G. Filippi, 'Patto di pace tra Ruggiero II Messina ${ }^{39} \quad$ Normanno e la Citta di Savona', Archivio (1127) storico per le provincie napoletane, 14 (1889), 753-7. ${ }^{40}$

Treaty of Messina Howden, Gesta, ii, 133-5. For the oath of the (1190) sureties, see Howden, Gesta, ii, 136. Translation Richard, k. of England in The Annals of Roger de Hoveden, ii, 164-6. Tancred, k. of Sicily

Treaty of Messina Dip. Docs, no. 5 (pp. 14-15).

1191

(1191)

Richard I, k. of England

Philip II (Augustus), k. of the Franks 


\begin{tabular}{|c|c|c|}
\hline Name of Treaty & Printed edition & Parties and date \\
\hline Treaty of Metz & $\begin{array}{l}\text { 'Hludowici et Karoli Pactiones Mettenses', in } \\
\text { MGH Capit. II, no. } 245 \text { (pp. 167-8). }\end{array}$ & $\begin{array}{l}867 \\
\text { Louis (the German), [k. of East Frankia] } \\
\text { Charles (the Bald), [k. of West Frankia] }\end{array}$ \\
\hline $\begin{array}{l}\text { Treaty of Milan } \\
\qquad(1158)\end{array}$ & $\begin{array}{l}\text { Gesta Friderici, 221-4. Translation in Otto of } \\
\text { Freising, The Deeds of Frederick Barbarossa, } \\
220-3 .\end{array}$ & $\begin{array}{l}1158 \\
\text { Frederick I, emperor } \\
\text { Milan }\end{array}$ \\
\hline $\begin{array}{l}\text { Treaty of Milan } \\
\qquad(1196)\end{array}$ & ACM, no. 194 (pp. 272-9). & $\begin{array}{l}1196 \\
\text { Milan } \\
\text { Como }\end{array}$ \\
\hline $\begin{array}{l}\text { Treaty of } \\
\quad \text { Montebello }\end{array}$ & DD FI, iii, no. 638 (pp. 135-8). & $\begin{array}{l}1175 \\
\text { Frederick I, emperor } \\
\text { Cities of the Lombard League }\end{array}$ \\
\hline $\begin{array}{l}\text { Treaty of } \\
\text { Montferrand }\end{array}$ & $\begin{array}{l}\text { Howden, Gesta, i, 36-41. A summary of the terms } \\
\text { in English can be found in The Annals of Roger } \\
\text { de Hoveden, i, 362-8. }\end{array}$ & $\begin{array}{l}1173 \\
\text { Henry II, k. of England } \\
\text { Humbert III, c. of Maurienne }\end{array}$ \\
\hline $\begin{array}{l}\text { Treaty of } \\
\text { Montlouis }\end{array}$ & $\begin{array}{l}\text { Howden, Gesta, i, 77-9; Howden, Chronica, ii, } \\
\text { 67-9. Translation in The Annals of Roger de } \\
\text { Hoveden, i, 386-8. }\end{array}$ & $\begin{array}{l}1174 \\
\text { Henry II, k. [of England] } \\
\text { Henry (the Young King), k. [of England] } \\
\text { Richard }{ }^{42} \\
\text { Geoffrey }\end{array}$ \\
\hline
\end{tabular}


Treaty of Najac-
de-Rouergue (1185)

Treaty of Naples

\section{Treaty of \\ Nonancourt \\ (1189)}

\section{Treaty of Novgorod}

\section{Treaty of Oribuela}

Treaty of Oristano I
R. Benjamin, 'A Forty Years War: Toulouse and the Plantagenets, 1156-96', Historical Research, 61 (1988), 283-5.

CDRG, iii, no. 2 (pp. 4-12); LIRG, vol. 1/2, no. 286 (pp. 28-34). For a partial English translation, see Hall, Caffaro, 203.

Rec. des actes de Philippe Auguste, i, no. 287 (with division into clauses); Diceto, ii, 73. For German translation, see A. Cartelliere, Philipp II August. König von Frankreich, 4 vols. (Leipzig, 1899-1906), ii, 92-3.

Swedish translation in Sveriges traktater med främmande magter. Första delen 822-1335, ed. O. S. Rydberg (Stockholm, 1877), no. 52 (pp. 106-8); German translation in Hansische Urkundenbuch. Band I, ed. Konstantin Höhlbaum (Halle, 1876), no. 50 (pp. 26-7).

'Treaty of Tudmir', in Reading the Middle Ages: Sources from Europe, Byzantium, and the Islamic World, 79.

LIRG, vol. 1/2, no. 393 (pp. 342-4).
1185

Alfonso II, k. of Aragon

Richard, c. of Poitou and son of the king of England

\section{1}

Henry VI, emperor

Genoa

1189

Richard I, k. of England

Philip II, k. of the Franks

c. 1199

Jaroslaw, prince of Novgorodians Germans $^{43}$

Gotlanders

c. 713

Theodemir, ${ }^{44}$ c. of Murcia ${ }^{45}$

Abd al-Aziz, leader of Muslim forces in Spain

1192

Hugh I, k. of Arborea

Genoa 


\begin{tabular}{|c|c|c|}
\hline Name of Treaty & Printed edition & Parties and date \\
\hline $\begin{array}{l}\text { Treaty of } \\
\text { Oristano II }\end{array}$ & $\begin{array}{l}\text { LIRG, vol. 1/2, no. } 403 \text { (pp. 367-9). For oath of } \\
\text { the king, see same volume no. } 404 \text { (pp. 370-1). }\end{array}$ & $\begin{array}{l}1192 \\
\text { Peter, k. of Arborea }{ }^{46} \\
\text { Genoa }\end{array}$ \\
\hline Treaty of Orvieto & MGH Const. I, no. 325 (pp. 464-5). & $\begin{array}{l}1186 \\
\text { Henry VI, k. of the Romans } \\
\text { Hugh III, d. of Burgundy }{ }^{47}\end{array}$ \\
\hline $\begin{array}{l}\text { Treaty of Pavia } \\
\qquad(715)\end{array}$ & $\begin{array}{l}\text { Peter Classen, Politische Verträge des frühen } \\
\text { Mittelalters (Germering, 1966), no. } 19 \\
\text { (pp. 54-5). }\end{array}$ & $\begin{array}{l}715 \text { (or } 730)^{48} \\
\text { Liudprand, k. of the Lombards } \\
\text { Comacchio, represented by the priest Lupicino, } \\
\text { the magister militum Bertarene and the 'comites' } \\
\text { Mauro and Stefano }\end{array}$ \\
\hline $\begin{array}{l}\text { Treaty of Pavia } \\
\qquad(840)\end{array}$ & $\begin{array}{l}\text { Pactum Hlotharii I, in MGH Capit. II, no. } 233 \\
\text { (pp. 130-5). }\end{array}$ & $\begin{array}{l}840 \\
\text { Lothar I, emperor } \\
\text { Peter, d. of the Venetians }\end{array}$ \\
\hline $\begin{array}{l}\text { Treaty of Pavia } \\
\quad(1162)\end{array}$ & DD FI, ii, no. 357 (p. 204). & $\begin{array}{l}1162 \\
\text { Frederick I, emperor } \\
\text { Pisa }\end{array}$ \\
\hline $\begin{array}{l}\text { Treaty of Pavia } \\
\qquad(1175)\end{array}$ & CDRG, II, no. 101 (pp. 227-31). & $\begin{array}{l}1175 \\
\text { Genoa } \\
\text { Pisa }\end{array}$ \\
\hline
\end{tabular}




\begin{tabular}{|c|c|c|}
\hline $\begin{array}{l}\text { Treaty of } \\
\quad \text { Palermo } \\
\text { (1156) }\end{array}$ & $\begin{array}{l}\text { Main text in CDRG, I, no. } 279 \text { (pp. 339-41). For } \\
\text { the oath of William I, see Guillelmi I. Regis } \\
\text { Diplomata, ed. H. Enzensberger (Cologne, } \\
\text { 1996), no. } 17 \text { (p. 48); CDRG, I, no. } 280 \\
\text { (pp. 341-2). For the oath of the Genoese, see } \\
\text { CDRG, I, no. } 282 \text { (pp. 344-9). }\end{array}$ & $\begin{array}{l}1156 \\
\text { William I, k. of Sicily } \\
\text { Genoa }\end{array}$ \\
\hline $\begin{array}{l}\text { Treaty of } \\
\quad \text { Palermo } \\
\text { (1174) }\end{array}$ & CDRG, II, no. 94 (pp. 202-4). & $\begin{array}{l}1174 \\
\text { William II, k. of Sicily } \\
\text { Genoa }\end{array}$ \\
\hline $\begin{array}{l}\text { Treaty of } \\
\text { Péronne }\end{array}$ & Rec. des actes de Philippe Auguste, ii, no. 621. & $\begin{array}{l}1200 \\
\text { Philip II, k. of Franks } \\
\text { Baldwin IX, c. of Flanders }\end{array}$ \\
\hline $\begin{array}{l}\text { Treaty of } \\
\text { Piacenza } \\
\text { (1167) }\end{array}$ & $\begin{array}{l}A C M, \text { no. } 55(82-3) \text {. For the draft articles of the } \\
\text { treaty (agreed in Cremona) and the oaths of the } \\
\text { citizens of Milan, Bergamo and Cremona, see } \\
\text { ACM, nos. 50-2 (pp. 73-6). }\end{array}$ & $\begin{array}{l}1167 \\
\text { Milan } \\
\text { Bergamo } \\
\text { Mantua } \\
\text { Cremona }\end{array}$ \\
\hline Treaty of Pisa & $\begin{array}{l}\text { F. Bonaini, 'Due carte pisano-amalfitane', Archivio } \\
\text { storico italiano, 3rd ser., } 8 \text { (1868), 5-7. }\end{array}$ & $\begin{array}{l}1126 \\
\text { Pisa } \\
\text { Amalfi }\end{array}$ \\
\hline $\begin{array}{l}\text { Treaty of } \\
\quad \text { Portovenere } \\
\text { (1149) }\end{array}$ & CDRG, I, no. 195 (pp. 243-7). & $\begin{array}{l}1149 \\
\text { Genoa } \\
\text { Pisa }\end{array}$ \\
\hline
\end{tabular}




\begin{tabular}{|c|c|c|}
\hline Name of Treaty & Printed edition & Parties and date \\
\hline $\begin{array}{l}\text { Treaty of } \\
\text { Portovenere } \\
\text { (1169) }\end{array}$ & CDRG, II, no. 48 (pp. 99-102). & $\begin{array}{l}1169 \\
\text { Genoa } \\
\text { Pisa }\end{array}$ \\
\hline $\begin{array}{l}\text { Treaty of } \\
\text { Ravenna }\end{array}$ & $\begin{array}{l}\text { 'Pactum Karoli III', in MGH Capit. II, no. } 236 \\
\text { (pp. 138-41). }\end{array}$ & $\begin{array}{l}880 \\
\text { Charles (the Fat), k. } \\
\text { Urse, d. of the Venetians }\end{array}$ \\
\hline $\begin{array}{l}\text { Treaty of Rialto }{ }^{49} \\
\quad(933)\end{array}$ & UHSRV, I, no. 11 (pp. 11-16). & $\begin{array}{l}933 \\
\text { Peter II Candiano, d. of Venice } \\
\text { Wintherius, margrave }{ }^{50} \text { of Istria }\end{array}$ \\
\hline $\begin{array}{l}\text { Treaty of Rialto } \\
\quad(1145)\end{array}$ & UHSRV, I, no. 48 (pp. 105-7). & $\begin{array}{l}1145 \\
\text { Peter Polani, d. of Venetians } \\
\text { Justinopolis }\end{array}$ \\
\hline $\begin{array}{l}\text { Treaty of Rome } \\
\quad(824)\end{array}$ & $\begin{array}{l}\text { 'Constitutio Romana', in MGH Capit. I, no. } 161 \\
\text { (pp. 322-4). }\end{array}$ & $\begin{array}{l}824 \\
\text { Lothar I, emperor } \\
\text { (Louis the Pious, emperor) }{ }^{52} \\
\text { Eugenius II, pope }\end{array}$ \\
\hline $\begin{array}{l}\text { Treaty of Rome } \\
\quad \text { (962) }\end{array}$ & $\begin{array}{l}\text { Die Urkunden der deutschen Könige und Kaiser. } \\
\text { Erster Band. Die Urkunden Konrad I, Heinrich } \\
\text { I und Otto I, ed. T. Sickel (Hanover, 1879-84), } \\
\text { no. } 235 \text { (pp. 322-7). }\end{array}$ & $\begin{array}{l}962 \\
\text { Otto I, emperor } \\
\text { John XII, pope }\end{array}$ \\
\hline $\begin{array}{l}\text { Treaty of Rome } \\
\text { (967) }\end{array}$ & $\begin{array}{l}\text { Die Urkunden der deutschen Könige und Kaiser. } \\
\text { Erster Band. Die Urkunden Konrad I, Heinrich } \\
\text { I und Otto I, no. } 350 \text { (pp. 478-83). }\end{array}$ & $\begin{array}{l}967 \\
\text { Otto I, emperor } \\
\text { Venice }\end{array}$ \\
\hline
\end{tabular}




\begin{tabular}{|c|c|c|}
\hline $\begin{array}{l}\text { Treaty of Rouen } \\
\text { (991) }\end{array}$ & $\begin{array}{l}\text { Chaplais, EDP, pp. 37-8. Translation in EHD, } \\
\text { I, no. } 230 .\end{array}$ & $\begin{array}{l}991 \\
\text { John XV, pope (arbiter), through his legate Leo } \\
\text { of Trevi } \\
\text { Ethelred, k. of the West Saxons }{ }^{53} \\
\text { Richard I, marquis }{ }^{54} \text { [of the Normans] }\end{array}$ \\
\hline $\begin{array}{l}\text { Treaty of Rouen } \\
\quad(1204)\end{array}$ & $\begin{array}{l}\text { Rec. des actes de Philippe Auguste, ii, no. } 803 \\
\quad \text { (pp. 379-81). }\end{array}$ & $\begin{array}{l}1204 \\
\text { Peter de Preaux, and other knights ('milites') } \\
\text { Robert, the mayor } \\
\text { Jurors ('jurati') and commune of Rouen } \\
\text { Philip II, k. of France }\end{array}$ \\
\hline $\begin{array}{l}\text { Treaty of } \\
\quad \text { Sahagún }\end{array}$ & González, El reino de Castilla, no. 44 (pp. 80-2). & $\begin{array}{l}1158 \\
\text { Sancho III, k. of Toledo and Castile } \\
\text { Ferdinand II, k. of Léon and Galicia }\end{array}$ \\
\hline Treaty of Salò & $\begin{array}{l}\text { 'Pactum Berengarii I' in MGH Capit. II, no. } 238 \\
\text { (pp. 143-7). }\end{array}$ & $\begin{array}{l}888 \\
\text { Berengar, k. [of Italy] } \\
\text { Peter, d. of the Venetians }\end{array}$ \\
\hline $\begin{array}{l}\text { Treaty of Sant } \\
\text { Feliu de } \\
\text { Guixols }\end{array}$ & $\begin{array}{l}\text { Liber maiolichinus de gestis pisanorum illustribus, } \\
\text { ed. C. Calisse (Rome, 1904), appendix } 1 \\
\text { (pp. 137-40). }\end{array}$ & $\begin{array}{l}1113 \\
\text { Pisa } \\
\text { Ramon Berenguer III, c. of Barcelona }\end{array}$ \\
\hline $\begin{array}{l}\text { Treaty of San } \\
\quad \text { Lorenzo }^{56}\end{array}$ & $\begin{array}{l}\text { LIRG, vol. 1/1, no. } 181 \text { (pp. 262-4). Translation } \\
\quad \text { in Hall, Caffaro, 195-6. }\end{array}$ & $\begin{array}{l}1155 \\
\text { Manuel Komnenos, emperor } \\
\text { Genoa }\end{array}$ \\
\hline
\end{tabular}




\begin{tabular}{|c|c|c|}
\hline Name of Treaty & Printed edition & Parties and date \\
\hline $\begin{array}{l}\text { Treaty of San } \\
\text { Salvatore I }\end{array}$ & DD FI, ii, no. 362 (pp. 212-14). & $\begin{array}{l}1162 \\
\text { Frederick I, emperor } \\
\text { Piacenza }\end{array}$ \\
\hline $\begin{array}{l}\text { Treaty of San } \\
\quad \text { Salvatore }{ }^{57} I I\end{array}$ & $\begin{array}{l}\text { DD FI, ii, no. } 367 \text { (pp. 220-25). A partial } \\
\text { translation in Hall, Caffaro, 196-203. }\end{array}$ & $\begin{array}{l}1162 \\
\text { Frederick I, emperor } \\
\text { Genoa }\end{array}$ \\
\hline $\begin{array}{l}\text { Treaty of Santa } \\
\text { Maria de } \\
\text { Vineis }\end{array}$ & $\begin{array}{l}\text { For the Genoese promise, see CDRG, II, no. } 131 \\
\quad \text { (pp. 266-8). For the promise of the city of } \\
\text { Alessandria, see same volume no. } 132(268-70) \text {. }\end{array}$ & $\begin{array}{l}1181 \\
\text { Genoa } \\
\text { Alessandria }\end{array}$ \\
\hline $\begin{array}{l}\text { Treaty of } \\
\quad \text { Sardinia }\end{array}$ & $L I R G$, vol. $1 / 2$, no. 415 (pp. 392-4) & $\begin{array}{l}1168 \\
\text { Peter, 'iudex' of Cagliari } \\
\text { Barisone, II, 'iudex' of Arboreans }\end{array}$ \\
\hline $\begin{array}{l}\text { Treaty of } \\
\quad \text { Savonnières }\end{array}$ & $\begin{array}{l}\text { 'Hludowici, Karoli et Hlotharii II conventus } \\
\text { apud Saponarias', in MGH Capit. II, no. } 243 \\
(\text { pp. 163-5) }\end{array}$ & $\begin{array}{l}862 \\
\text { Louis (the German), k. [of East Frankia] } \\
\text { Charles (the Bald), k. [of West Frankia] } \\
\text { Lothar II, k. [of Lotharingia] }\end{array}$ \\
\hline $\begin{array}{l}\text { Treaty of } \\
\quad \text { Seligenstadt }\end{array}$ & DD FI, iv, no. 970 (pp. 248-51). & $\begin{array}{l}1188 \\
\text { Frederick I, emperor } \\
\text { Alfonso VII, k. of Castile }\end{array}$ \\
\hline Treaty of Silistra & RPC, 89-90. & $\begin{array}{l}971 \\
\text { John Tzimiskes, emperor } \\
\text { Sviatoslav I, prince of Rus' }\end{array}$ \\
\hline
\end{tabular}




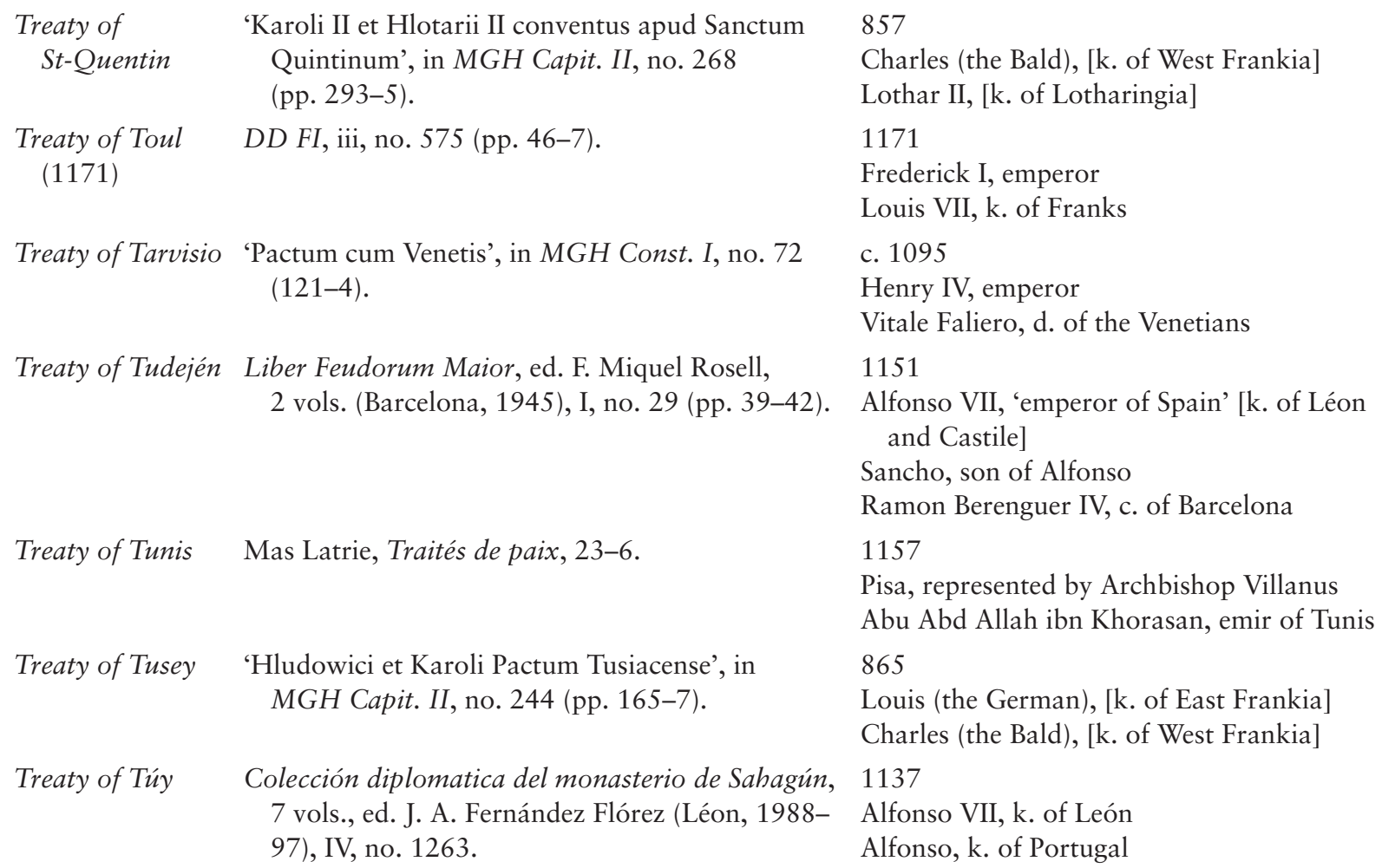

857

Charles (the Bald), [k. of West Frankia] Lothar II, [k. of Lotharingia]

1171

Frederick I, emperor

Louis VII, k. of Franks

c. 1095

Henry IV, emperor

Vitale Faliero, d. of the Venetians

1151

Alfonso VII, ‘emperor of Spain’ [k. of Léon and Castile]

Sancho, son of Alfonso

Ramon Berenguer IV, c. of Barcelona

1157

Pisa, represented by Archbishop Villanus

Abu Abd Allah ibn Khorasan, emir of Tunis

865

Louis (the German), [k. of East Frankia]

Charles (the Bald), [k. of West Frankia]

1137

Alfonso VII, k. of León

Alfonso, k. of Portugal 


\begin{tabular}{|c|c|c|}
\hline Name of Treaty & Printed edition & Parties and date \\
\hline $\begin{array}{l}\text { Treaty of Tyre } \\
\text { (1187) }\end{array}$ & $\begin{array}{l}\text { LIRG, vol. 1/2, no. } 330 \text { (pp. 135-7). Translation } \\
\text { in Hall, Caffaro, 215-16. }\end{array}$ & $\begin{array}{l}1187 \\
\text { Genoa } \\
\text { The barons of the kingdom of Jerusalem }\end{array}$ \\
\hline $\begin{array}{l}\text { Treaty of Tyre } \\
\text { (1189) }\end{array}$ & $L I R G$, vol. $1 / 2$, no. 342 (pp. 160-1). & $\begin{array}{l}1189 \\
\text { Bohemond III, prince of Antioch } \\
\text { Genoa }\end{array}$ \\
\hline $\begin{array}{l}\text { Treaty of Tyre } \\
\quad(1190)\end{array}$ & $\begin{array}{l}\text { LIRG, vol. 1/2, no. } 331 \text { (pp. 137-40). Translation } \\
\text { in Hall, Caffaro, 215-16. }\end{array}$ & $\begin{array}{l}1190 \\
\text { Genoa } \\
\text { Conrad of Montferrat, lord of Tyre }\end{array}$ \\
\hline $\begin{array}{l}\text { Treaty of Tyre } \\
\quad(1192)\end{array}$ & $\begin{array}{l}\text { LIRG, vol. 1/2, no. } 334 \text { (pp. 144-6). Translation } \\
\text { in Hall, Caffaro, 223-4. }\end{array}$ & $\begin{array}{l}1192 \\
\text { Genoa, through its representative William Riccio } \\
\text { Conrad of Montferrat, lord of Tyre }\end{array}$ \\
\hline $\begin{array}{l}\text { Treaty of } \\
\quad \text { Valenciennes }\end{array}$ & $\begin{array}{l}\text { 'Hlotharii et Karoli Conventus Valentianas', in } \\
\text { MGH Capit. II, no. } 206 \text { (pp. 75-6). }\end{array}$ & $\begin{array}{l}853 \\
\text { Lothar I, [emperor] } \\
\text { Charles (the Bald), [k. of West Frankia] }\end{array}$ \\
\hline $\begin{array}{l}\text { Treaty of Venice } \\
\qquad I(1177)\end{array}$ & $\begin{array}{l}\text { DD FI, iii, no. } 687 \text { (pp. 202-6). Translation in } \\
\text { E. F. Henderson, Select Historical Documents of } \\
\text { the Middle Ages (London, 1896), 425-30. }\end{array}$ & $\begin{array}{l}1177 \\
\text { Frederick I, emperor } \\
\text { Alexander III, pope }\end{array}$ \\
\hline $\begin{array}{l}\text { Treaty of Venice } \\
\qquad I I(1177)\end{array}$ & $\begin{array}{l}\text { Chronicon Romualdi Salernitani, ed. C. A. Garufi } \\
\text { (Citta di Castello, 1935), 291-2. }\end{array}$ & $\begin{array}{l}1177 \\
\text { Frederick I, emperor } \\
\text { William II, k. of Sicily }\end{array}$ \\
\hline
\end{tabular}


Treaty of Venice III (1177)

Treaty of Verona (983)

Treaty of Verona (1111)

\section{Treaty of Westminster (1153) \\ Treaty of Windsor}

Treaty of Worms
DD FI, iii, no. 695 (pp. 218-22).

Die Urkunden der deutschen Könige und Kaiser. Zweiten Bandes erster Theil. Die Urkunden Otto des II (Hanover, 1888), no. 300 (pp. 352-6). The announcements are in same volume, nos. 298-9 (pp. 350-2).

MGH Const. I, no. 102 (152-6).

Regesta Regum Anglo-Normannorum, 3 vols., eds. H. A. Cronne and R. H. C. Davis (Oxford, 1968), iii, no. 272.

Howden, Gesta, I, 102-3; Howden, Chronica, II, 84-5. Translation in The Annals of Roger de Hoveden, i, 402-4.

Howden, Chronica, iii, 215-16. Translation in The Annals of Roger de Hoveden, ii, 296-7.
1177

Frederick I, emperor Sebastian Ziani, d. of Venice

983

Otto II, emperor

Tribuno Menio, d. of Venetians

1111

Henry V, emperor

Ordelafo Faliero, d. of Venetians

1153

Stephen, k. of England

Henry, d. of Normandy

1175

Henry II, k. of England

Rory, k. of Connacht

1193

Henry VI, emperor

Richard I, k. of England 


\begin{tabular}{|c|c|c|}
\hline Name of Treaty & Printed edition & Parties and date \\
\hline $\begin{array}{l}\text { Treaty of } \\
\text { Würzburg }\end{array}$ & Historia de expeditione, 103-5. & $\begin{array}{l}1193 \\
\text { Henry VI, emperor } \\
\text { Leopold, d. of Austria }\end{array}$ \\
\hline Treaty of York & $\begin{array}{l}\text { Howden, Gesta, I, 96-9; Howden, Chronica, II, } \\
\text { 80-2. Translation in The Annals of Roger de } \\
\text { Hoveden, i, 398-401. }\end{array}$ & $\begin{array}{l}1175 \\
\text { Henry II, k. of England } \\
\text { William I, k. of Scots }\end{array}$ \\
\hline $\begin{array}{l}\text { Treaty of } \\
\text { Zaragoza }\end{array}$ & $\begin{array}{l}\text { González, El reino de Castilla, no. } 147 \\
\quad \text { (pp. 251-3). }\end{array}$ & $\begin{array}{l}1170 \\
\text { Alfonso VIII, k. of Castile } \\
\text { Alfonso II, k. of Aragon }\end{array}$ \\
\hline $\begin{array}{l}\text { Treaty between } \\
\text { Alfred and } \\
\text { Guthrum }\end{array}$ & $\begin{array}{l}\text { Die Gesetze, i, 126-8. Translation in EHD, } I \text {, } \\
\quad 380-1 .\end{array}$ & $\begin{array}{l}880 \times 890 \\
\text { Alfred, king of the West Saxons } \\
\text { Guthrum, king of the people in East Anglia }\end{array}$ \\
\hline $\begin{array}{l}\text { Treaty between } \\
\text { Baldwin of } \\
\text { Jerusalem and } \\
\text { Genoa }\end{array}$ & $\begin{array}{l}\text { LIRG, vol. 1/1, nos. 60-1 (pp. 98-102). The } \\
\text { first document is the oath of the Genoese, the } \\
\text { second, the terms and obligations of the king. } \\
\text { Translation in Hall, Caffaro, 174-6. }\end{array}$ & $\begin{array}{l}1104 \\
\text { Baldwin I, k. of Judaea and Jerusalem } \\
\text { Genoa }\end{array}$ \\
\hline $\begin{array}{l}\text { Treaty between } \\
\text { Barisone II of } \\
\text { Arborea and } \\
\text { Barisone II of } \\
\text { Torres }\end{array}$ & $\begin{array}{l}\text { LIRG, vol. } 1 / 2 \text {, no. } 390 \text { (pp. } 335-7 \text { ). For the } \\
\text { oaths of Barisone of Torres and the Genoese } \\
\text { mediator, see no. } 391 \text { of the same volume } \\
\text { (pp. 337-8). }\end{array}$ & $\begin{array}{l}1168 \\
\text { Barisone II, ‘iudex'of Arborea } \\
\text { Barisone II, 'iudex' of Torres }\end{array}$ \\
\hline
\end{tabular}




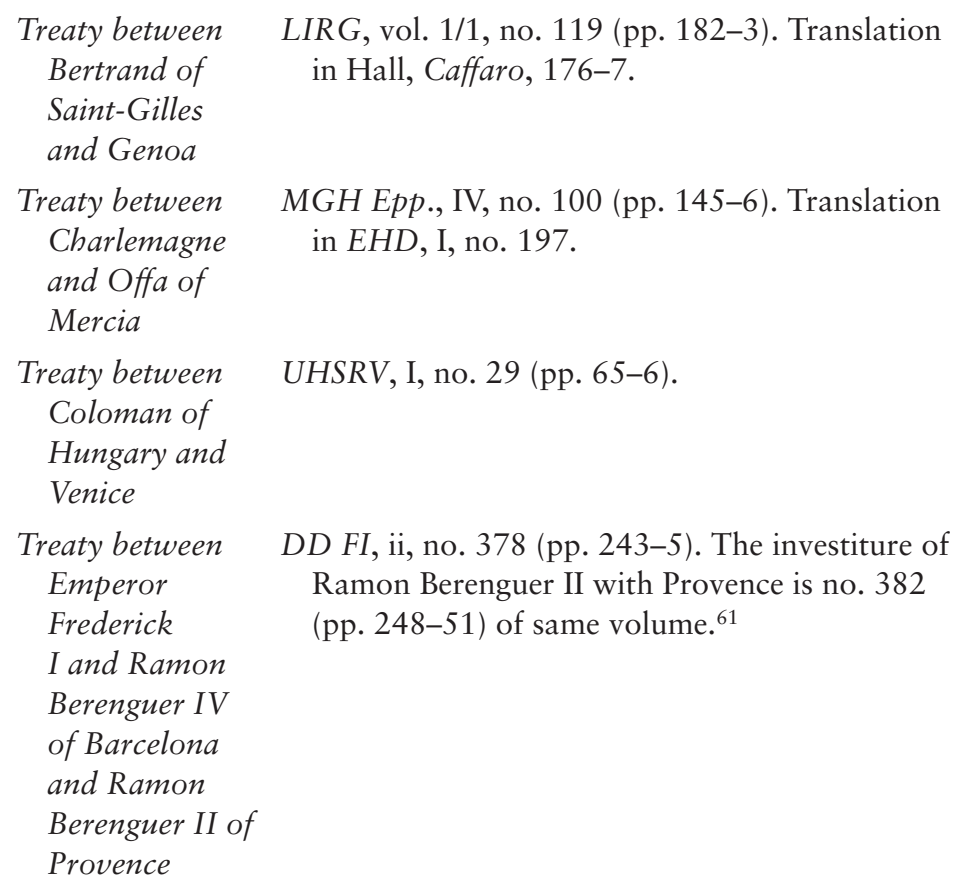

1109

Bertrand, c. of Saint-Gilles ${ }^{60}$

Genoa

796

Charles, k. of the Franks and the Lombards Offa, k. of the Mercians

\section{$1098 \times 1101$}

Coloman, k. of the Hungarians

Vitale I Michiele, d. of Venetians

\section{2}

Frederick I, emperor

Ramon Berenguer IV, c. of Barcelona

Ramon Berenguer II, c. of Provence 


\begin{tabular}{|c|c|c|}
\hline Name of Treaty & Printed edition & Parties and date \\
\hline $\begin{array}{l}\text { Treaty between } \\
\text { Genoa and } \\
\text { Antibes }\end{array}$ & LIRG, vol. 1/1, no. 18 (pp. 28-9). & $\begin{array}{l}1138 \\
\text { Genoa } \\
\text { Antibes }\end{array}$ \\
\hline $\begin{array}{l}\text { Treaty between } \\
\text { Genoa and } \\
\text { Alfonso II of } \\
\text { Aragon }\end{array}$ & LIRG, vol. 1/2, no. 293 (pp. 54-7). & $\begin{array}{l}1167 \\
\text { Genoa } \\
\text { Alfonso II, k. of Aragon }\end{array}$ \\
\hline $\begin{array}{l}\text { Treaty between } \\
\text { Genoa and } \\
\text { Barisone II of } \\
\text { Torres (1166) }\end{array}$ & LIRG, vol. 1/2, no. 405 (pp. 371-2). & $\begin{array}{l}1166 \\
\text { Barisone II, ‘iudex’ of Torres } \\
\text { Genoa }\end{array}$ \\
\hline $\begin{array}{c}\text { Treaty between } \\
\text { Genoa and } \\
\text { Boabdil of } \\
\text { Valencia }^{62}\end{array}$ & $\begin{array}{l}\text { LIRG, vol. 1/1, no. } 118 \text { (pp. 180-1). Translation } \\
\text { in Hall, Caffaro, 190-1. }\end{array}$ & $\begin{array}{l}1149 \\
\text { Genoa, represented by William Lusio } \\
\text { 'Boabdil', }{ }^{63} \mathrm{k} \text {. of Valencia }\end{array}$ \\
\hline $\begin{array}{l}\text { Treaty between } \\
\text { Genoa and Fos }\end{array}$ & $\begin{array}{l}\text { LIRG, vol. } 1 / 1, \text { no. } 14 \text { (pp. } 22-3 \text { ). Translation in } \\
\text { Hall, Caffaro, } 177-8 .\end{array}$ & $\begin{array}{l}1138 \\
\text { Genoa } \\
\text { Fos }\end{array}$ \\
\hline $\begin{array}{l}\text { Treaty between } \\
\text { Genoa and } \\
\text { Fréjus }\end{array}$ & $L I R G$, vol. $1 / 1$, no. 16 (pp. 25-6). & $\begin{array}{l}1138 \\
\text { Genoa } \\
\text { Fréjus }\end{array}$ \\
\hline
\end{tabular}




\begin{tabular}{|c|c|c|}
\hline $\begin{array}{l}\text { Treaty between } \\
\text { Genoa and } \\
\text { Hyéres }\end{array}$ & LIRG, vol. 1/1, no. 17 (pp. 27-8). & $\begin{array}{l}1138 \\
\text { Genoa } \\
\text { Hyéres }\end{array}$ \\
\hline $\begin{array}{l}\text { Treaty between } \\
\text { Genoa and } \\
\text { Lucca }\end{array}$ & CDRG, I, no. 238 (pp. 287-8). & $\begin{array}{l}1153 \\
\text { Lucca } \\
\text { Genoa }\end{array}$ \\
\hline $\begin{array}{l}\text { Treaty between } \\
\text { Genoa and } \\
\text { Marseille }\end{array}$ & LIRG, vol. 1/1, no. 15 (pp. 23-5). & $\begin{array}{l}1138 \\
\text { Genoa } \\
\text { Marseille }\end{array}$ \\
\hline $\begin{array}{c}\text { Treaty between } \\
\text { Genoa and } \\
\text { Narbonne }\end{array}$ & CDRG, I, no. 62 (pp. 73-5). & $\begin{array}{l}1132 \\
\text { Genoa } \\
\text { Narbonne, through representatives of } \\
\text { Viscount Aimery, Archbishop Arnold } \\
\text { and the people of the city }\end{array}$ \\
\hline $\begin{array}{l}\text { Treaty between } \\
\text { Genoa and } \\
\text { Pavia (1130) }\end{array}$ & CDRG, I, no. 56 (pp. 66-7). & $\begin{array}{l}1130 \\
\text { Genoa } \\
\text { Pavia }\end{array}$ \\
\hline $\begin{array}{c}\text { Treaty between } \\
\text { Genoa and } \\
\text { Pavia (1140) }\end{array}$ & $C D R G$, I, no. 105 (pp. 124-6). & $\begin{array}{l}1140 \\
\text { Genoa } \\
\text { Pavia }\end{array}$ \\
\hline
\end{tabular}




\begin{tabular}{|c|c|c|}
\hline Name of Treaty & Printed edition & Parties and date \\
\hline $\begin{array}{l}\text { Treaty between } \\
\text { Genoa and } \\
\text { Peter of } \\
\text { Arborea }\end{array}$ & $\begin{array}{l}\text { LIRG, vol. 1/2, no. } 397 \text { (pp. 354-5). For the } \\
\text { oaths, see same volume nos. 398-9 (pp. 356-9); } \\
\text { the initial undertaking is no. } 401 \text { (pp. 361-3) } \\
\text { and the confirmation no. } 402 \text { (pp. 364-6). }\end{array}$ & $\begin{array}{l}1189 \\
\text { Peter, k. of Arborea } \\
\text { Genoa }\end{array}$ \\
\hline $\begin{array}{l}\text { Treaty between } \\
\text { Genoa and } \\
\text { Ramon } \\
\text { Berenguer III } \\
\text { of Barcelona }\end{array}$ & $C D R G, \mathrm{I}, 46$ (pp. 55-7) & $\begin{array}{l}1127 \\
\text { Ramon Berenguer III, c. of Barcelona } \\
\text { Genoa }\end{array}$ \\
\hline $\begin{array}{l}\text { Treaty between } \\
\text { Genoa and } \\
\text { Raymond of } \\
\text { Toulouse }\end{array}$ & LIRG, vol. 1/2, nos. 360-1 (pp. 226-30). & $\begin{array}{l}1171 \\
\text { Raymond V, c. of Toulouse } \\
\text { Genoa }\end{array}$ \\
\hline $\begin{array}{l}\text { Treaty between } \\
\text { Genoa and } \\
\text { Raymond } \\
\text { of Toulouse, } \\
\text { Sancho of } \\
\text { Provence, } \\
\text { William of } \\
\text { Forcalquier }\end{array}$ & LIRG, vol. 1/2, no. 365 (pp. 253-5). & $\begin{array}{l}1184 \\
\text { Raymond V, c. of Toulouse } \\
\text { Sancho, c. of Provence } \\
\text { William IV, c. of Forcalquier } \\
\text { Genoa }\end{array}$ \\
\hline
\end{tabular}


Treaty between Genoa and

Tortona

Treaty between Llywelyn and the representatives of King John (1201)

Treaty between Milan and Piacenza

Treaty between Mu-Tsung of China and Tritsuk Detsen of Tibet

Treaty between Pisa and AbuYusuf-Yakub of the Almohads
LIRG, vol. 1/1, no. 23 (pp. 35-6).

The Acts of Welsh Rulers 1120-1283, no. 221 (pp. 371-3).

ACM, nos. 35-6 (pp. 55-6). The first document is the obligations of the Milanese and the second the obligations of Piacenza.

Richardson, 'The Sino-Tibetan Treaty Inscription', 821/2 137-162; Sources of Tibetan Tradition, 77-8.

For Italian translation of the Arabic original, see Mas Latrie, Traités de paix, 28-30.
1138

Genoa

Tortona

1201

John, k. of England, through his representatives Llywelyn ap Iorwerth ${ }^{64}$

1156

Milan

Piacenza

Mu-Tsung, Tang emperor of China Tritsuk-Detsen, emperor of Tibet

1186

Pisa

Abu-Yusuf-Yakub al-Mansur, emir of the Almohads 


\begin{tabular}{|c|c|c|}
\hline Name of Treaty & Printed edition & Parties and date \\
\hline $\begin{array}{l}\text { Treaty between } \\
\text { Sancho IV of } \\
\text { Navarre and } \\
\text { al-Muktadir } \\
\text { of Zaragoza } \\
(1069)\end{array}$ & $\begin{array}{l}\text { J. M. Lacarra 'Dos Tratados de paz y alianza entre } \\
\text { Sancho el de Peñalén y Moctadir de Zaragoza } \\
\text { (1069 y 1073)', in Homenaje a Johannes } \\
\text { Vincke, } 2 \text { vols. (Madrid, 1962-3), i, 131-3. }\end{array}$ & $\begin{array}{l}1069 \\
\text { Sancho IV 'of Peñalén', k. of Pamplona } \\
\text { 'Almuktadir bille', [k.] of Zaragoza }\end{array}$ \\
\hline $\begin{array}{l}\text { Treaty between } \\
\text { Sancho IV of } \\
\text { Navarre and } \\
\text { al-Muktadir } \\
\text { of Zaragoza } \\
(1073)\end{array}$ & Lacarra 'Dos Tratados de paz', 133-4. & $\begin{array}{l}1073 \\
\text { Sancho IV ‘of Peñalén', k. of Pamplona } \\
\text { 'Almuctadir uille', [k.] of Zaragoza }\end{array}$ \\
\hline $\begin{array}{l}\text { Treaty between } \\
\text { Sergius VII of } \\
\text { Naples and } \\
\text { Gaeta }\end{array}$ & Martin, Guerre, no. 7 (pp. 224-5). & $\begin{array}{l}1129 \\
\text { Sergius VII, d. of Naples and 'magister militum' } \\
\text { The people of Gaeta }{ }^{67}\end{array}$ \\
\hline $\begin{array}{l}\text { Treaty between } \\
\text { Venice and } \\
\text { Byzantium } \\
(1082 \times 1092)\end{array}$ & $\begin{array}{l}\text { I trattati con Bisanzio, 992-1198, no. } 2 \text { (pp. } \\
\text { 37-43); UHSRV, I, 51-4. }\end{array}$ & $\begin{array}{l}1082 \times 1092^{68} \\
\text { Alexios I Komnenos, emperor } \\
\text { [not known], d. of the Venetians }\end{array}$ \\
\hline
\end{tabular}


Treaty between

Venice and

Byzantium

(1147)

Treaty between

Venice and

Byzantium

(1187)

Truce of Aleppo (969)

Truce of Venice

(1177)

Truce of Verneuil 70
UHSRV, I, no. 51 (113-24).

UHSRV, I, nos. 70-2 (pp. 179-203).

The Truce of Safar A.H. 359. December-January 969-970, ed. Wesam Farag (Birmingham, 1977), 4-7.

DD FI, iii, no. 689 (pp. 207-8). For edition with clauses, see ACM, no. 110 (pp. 151-3).

Howden, Chronica, iii, 257-60. Translation in The Annals of Roger de Hoveden, ii, 329-32.
1147

Manuel I Komnenos, emperor

[not specified $]^{69} \mathrm{~d}$. of the Venetians

1187

Isaac II Angelos, emperor

Orio Mastropiero, d. of the Venetians

969

Nikephoros II Phokas, emperor, through his representative Petros

Qarquya, emir of Aleppo

1177

Frederick I, Emperor

The cities of the Lombard League

1194

Richard I, k. of England

Philip II, k. of France

\footnotetext{
${ }^{1}$ Only the oath of Henry IV survives from this controversial event, but it can be compared with Pope Gregory VII's account of it in a letter sent to the archbishops and bishops across Europe, for which see Gregory VII, Registrum IV, 12, in MGH Epp. sel. 2.1, 312-14.

2 The text simply refers to Henry as king, but different versions of the oath in different manuscripts and textual traditions use 'imperator' (emperor) and 'rex Teutonicorum' (king of the Germans), the latter clearly intended as an insult by Gregory's supporters.
} 
${ }^{3}$ In dealing with the so-called 'Pactum' of Arichis, I am convinced by, and have followed, the analysis of Jean-Marie Martin, showing that this document is, in fact, two. Martin, Guerre, 9-11.

${ }^{4}$ On the date, see Martin, Guerre, 78-82.

${ }^{5}$ It is difficult to know exactly who or what this referred to. The term 'iudex' can be translated directly as 'judge' and it is possible that this is what it meant. However, it may also have indicated a ruler or governor of the city. Cf. 'iudex' of Arborea/Cagliari.

${ }^{6}$ Additional information on the treaty can be found in the Chronicon Salernitanum. A Critical Edition with Studies on Literary and Historical Sources and on Language, ed. Ulla Westerbergh (Stockholm, 1953).

7 This phrase is usually translated as 'master of the soldiers', and certainly indicated the military leader of the duchy of Naples ('ducati Neapolitani'), hence why modern historiography tends to refer to him, and other Neapolitan leaders, as 'duke' (dux). Later treaties tend to be explicit about the link between the two titles: 'dux atque magister militum' Martin, Guerre, 223-4.

${ }^{8}$ Additional information on the treaty can be found in the Chronicon Salernitanum. A Critical Edition with Studies on Literary and Historical Sources and on Language, ed. Ulla Westerbergh (Stockholm, 1953).

${ }^{9}$ The treaty is frequently referred to as 'Pactum Warmundi' after the negotiator Warmund, patriarch of Jerusalem. The text is clear, however, that it was concluded at Acre ('apud Acron').

${ }^{10}$ King Baldwin II was in captivity during the conclusion of the treaty but the long prologue is clear that his representatives concluded it based on earlier proposals by the king ('...eiusdem regis Balduini promissiones secundum litterarum suarum et nuntiorum prolocutiones...'). Furthermore, c. 9 sets out that the king would ratify the treaty if he was released from captivity, or in the event he was not and a new king was elected, ratification of these terms would be a condition for the elevation to the throne. In the event, it was the former that came true and the treaty was confirmed by Baldwin II in 1125 .

11 The text notes that the treaty was concluded 'in obsidione Acconensi', that is, during the siege of Acre. The treaty was subsequently confirmed in Jaffa in 1191 at the request of King Richard I of England. LIRG, vol. 1/2, no. 333 (pp. 142-3).

12 The text calls him 'king of the Latins in the holy city of Jerusalem (in sancta civitate Ierusalem rex latinorum)'. Cf. Treaty between Baldwin of Jerusalem and Genoa (1104); Treaty of Acre (1124)

13 The two different documents and obligations that make up this treaty do not mention the place. The grant of privileges mentions that it was enacted on 14 July 1098, only two weeks after the city had fallen to the crusaders, and that it was sealed and signed by Bohemond himself with the Genoese representatives as witnesses. There seems no reason to doubt that this took place at Antioch, the authority over which was at this time disputed between Bohemond and Raymond of Toulouse - a fact mentioned in the Genoese commitments. On the historical context, see Thomas S. Asbridge, The Creation of the Principality of Antioch 1098-1130 (Woodbridge, 2000), 34-7. 
${ }^{14}$ Neither text gives Bohemond a title other than 'lord' (dominus), although the grant of privileges calls him 'son of Robert Guiscard duke of Apulia.'

15 Tancred has no title in the text, which has a much-debated history, for which see CDRG, i, 16-17. He was the regent of Antioch during the captivity of Bohemond I.

16 The text is clear that this agreement was made 'in camera domini patriarche Antiochie (in the chamber of the lord patriarch of Antioch)'.

17 The text refers to the doge but without specifically naming one. Judging by the date, this was Vitale II Michiele.

18 There was an additional renewal of this agreement in 1144 (LIRG, vol. 1/2, no. 338), which I have not listed separately here because the text simply confirmed the previous grants without outlining the actual terms or privileges.

${ }^{19}$ Medieval Sardinia consisted of four independent entities (judicati) - Arborea, Gallura, Cagliari, and Torres - each with a ruler called iudex (judge). Note, however, that some treaties also refer to each of these rulers as king (rex).

20 The text specifically notes it was concluded in the chapel of the palace.

21 The text states 'Actum est hoc ante ecclesiam Sanctorum Cosme et Damiani in Silice', identifiable as the Basilica of Cosmas and Damian located in the Forum of Vespasian in Rome, also known as the Forum of Peace. On this church in the twelfth century, see Pier Luigi Tucci, The Temple of Peace in Rome (Cambridge, 2017), 695-732.

${ }^{22}$ Near the town of San Miniato on the Via Francigena, i.e., the pilgrim route from France to Rome. It is now an archaeological site. According to the text, the treaty was concluded in 'domo Rambotti', the house of Rambotto.

${ }^{23}$ Near the north Italian town of Guastalla, as the text states: 'Viridi Coreggia prope Wartstallum'.

24 Wife of Duke John III of Gaeta (978-1008), who assumed the regency of her grandson, Duke John V, in c. 1025. On the historical context, see Patricia Skinner, Family Power in Southern Italy. The Duchy of Gaeta and its Neighbours, 850-1139 (Cambridge, 1995), 151, $173,273-4$.

25 Sister of Sergius IV of Naples and wife of Duke John IV of Gaeta (993-1011/12).

26 'Gagetanos magnes et mediocres', lit. 'Gaetans great and ordinary', which a little later in same document become 'Gaietanos maiores et minores', lit. 'Gaetans great and small'.

27 The treaty specifies it was written 'in territorio Novariense in obsidione castri Galliate'; that is, in the province of Novara during the siege of Galliate.

${ }^{28}$ In the text Alfonso claims to be 'Hyspaniarum imperator' but more realistically he was king of León-Castille.

${ }^{29}$ The text states the treaty was concluded 'actum Ianue, in publico parlamento', i.e., at the public assembly of the city. 
30 The text gives no title to Hugh but the reference to him being the son of Hugh de Bassio is a recognition of him reclaiming the viscounty of Besalù in the principality of Catalonia. Elsewhere in treaties with Genoa, he is referred to as Hugh I, king (or judge) of Arborea.

31 The actual text of this treaty has not survived, but its terms can be gleaned from the announcement of the English king, who mediated the agreement. Here, as also in the main text, I indicate this fact by not italicising the title of the treaty. The treaty was confirmed in the same year at a meeting at La Grange Saint Arnoul and then renegotiated in 1185 at Boves, but neither text has survived.

32 It is worth noting that Ralph de Diceto gives the place for this treaty as Nonancourt, the ford at which was a well-known meeting place between the kings but a location that is some 14 miles from Ivry.

${ }^{33}$ Text states: 'Acta fuerunt apud Gernicam insulam'; that is enacted on the island of Jarnègues, which is situated in the river Rhône between Tarascon and Beaucaire.

${ }^{34}$ Identified as the modern Slovenian city of Koper (It: Capodistria).

35 The text states that the treaty was enacted 'in loco Lerici prope ubi dicitur Sancto Georgio iuxta portum ipsius loci', likely referring to St George's church (not to be confused with the current, sixteenth-century church) in the town of Lerici.

36 The dating clause of the treaty states that it was concluded between Gaillon and Vaudreuil (Dip. Docs., 18), but the contemporary chronicler Roger of Howden states that it had been agreed that the parties would meet at Louviers, roughly between the two locations, on the feast of St Hilary (13 January) to confirm the treaty. Howden, Chronica, iii, 305. On how Anglo-French treaties record meeting places, see Benham, PMA, 23.

37 On the place and date, see short summary of the manuscripts by Imperiale di Santangelo in CDRG, ii, 334 .

38 The first line of the treaty gives his Arabic title, 'Emir', but elsewhere in the document he is referred to as 'king of Mallorca'.

39 The text states that the Savonese came to Roger 'cum ipse resideret in cappella palatii sui messane', that is, while he was sitting (holding court?) in the chapel of his palace at Messina.

40 Abulafia, The Two Italies, 65-70, has a discussion and corrections of the text as given by Filippi.

${ }^{41}$ The text of the treaty notes that it was concluded 'in territorio Papie, in campo subtus Montebellum inter exercitum imperatoris et Lonbardie'; that is, in the territory of Pavia, in a field beneath Montebello between the army of the emperor and that of Lombardy.

42 Only Henry the Young king among Henry II's sons is referred to by any title in the text.

43 The Germans and the Gotlanders referred to in the text are groups of merchants.

${ }_{44}^{4}$ Named in the Arabic original as 'Tudmir', hence the traditional name of the treaty.

45 The text of the treaty states that the terms applied to seven cities: Orihuela, Valentilla, Alicante, Mula, Bigastro, Ello, and Lorca.

46 This treaty, concluded at the same time as that with Hugh I, recognised Peter as co-ruler of Arborea. 
47 The text refers to Hugh as being the duke of Dijon (dux Divionensis), a reference to the capital and commercial centre of the dukedom of Burgundy.

48 On the two possible dates of this treaty, see comments by Massimo Montanari, 'Il capitolare di Liutprando: note di storia dell'economia e dell'alimentazione', in La Civiltà Comacchiese e Pomposiana dalle origini preistoriche al tardo medioevo (Bologna, 1986$), 461 \mathrm{fn} .1$.

${ }^{49}$ The document notes that this treaty was 'acta vero Rivoalto', i.e., drawn up at Rialto, the central part of what eventually turned into the city of Venice, which was located on an islet and included the ducal palace and the basilica of St Mark. 'Venice' in this early period was often synonymous with the whole region/duchy rather than the city. For this, see Luigi Andrea Berto, The Political and Social Vocabulary of John the Deacon's 'Istoria Veneticorum' (Turnhout, 2013), 141-5.

50 The text refers to him as 'marchio'.

${ }^{51}$ According to the text, this agreement was concluded in the court of the Venetian doge ('actum est in curia domini nostri Petri Polani ducis') in 'Rivoalto'. Unlike the tenth-century treaties with Justinopolis, it is evident that this was a significant extension of Venetian power, with the first clause setting out that the citizens owed fealty to the duke and the church of St Mark, and the location of where it was done emphasises this.

${ }^{52}$ Louis is named in the text of the oath, presumably because he was the senior emperor, but narrative sources are clear that Lothar dealt with the conflict and concluded the treaty. ARF, s.a. 823-4. For the context, see O. Bertolini, 'Osservazioni sulla Constitutio Romana e sull Sacramentum Cleri et Populi Romani dell'anno 824', in his Scritti scelti di storia medioevale, 2 vols., ed. O. Banti (Livorno, 1968), II, 705-38.

53 The text refers to Æthelred as king of the West Saxons ('Saxonum Occidentalium regis’), though historians tend to think of him as king of the English.

54 The text calls Richard marchio (marquis), perhaps best translated, in practical terms, as 'leader' of the Normans.

55 Sant Feliu de Guíxols in the district of Gerona, north of the city of Barcelona, for which see Silvia Orvietani Busch, Medieval Mediterranean Ports. The Catalan and Tuscan Coasts, 1100 to 1235 (Leiden, 2001), map 1.

56 The text sets out that it was concluded in the church of San Lorenzo in Genoa.

57 Referring to the monastery of San Salvatore in Pavia, 'in the emperor's palace', according to the text, which also adds that this took place 'after the destruction of Milan and the "deditio" (surrender) of Brescia and Piacenza', i.e., after 11 May 1162. DD FI, ii, 225. A treaty with Cremona was concluded at San Salvatore a couple of days later (DD FI, ii, no. 369), which describes San Salvatore as located outside the gates of the city of Pavia ('extra portas civitatis Pavia') and divulges that this was the site of the emperor's chapel ('capella'). Two weeks later, the imperial court had moved on to Savignano near the city of Modena, where a treaty was concluded with the city of Ravenna (DD FI, ii, no. 372) 
${ }^{58}$ It is worth noting I have taken a different view of this treaty to the MGH editors, namely that the 'capitulary' that accompanies the announcements cannot be considered part of the treaty, other than to give a historical context from the perspective of Charles the Bald. For the context of how the documents were drawn up, see $A B$, s.a. 862.

59 The text specifically says the treaty was concluded 'in hospicio Bernardi de Templo', i.e. in the house of Bernard of the Temple. The treaty was renewed with some small amendments by Henry de Troyes (count of Champagne), lord of Tyre, in 1192, for which see LIRG, vol. 1/ 2, no. 335 (pp. 146-9).

${ }^{60}$ The text refers to Bertrand as count of Saint-Gilles, a nod to his claim to the county of Toulouse, for which see Kevin James Lewis, The Counts of Tripoli and Lebanon in the Twelfth Century: Sons of Saint-Gilles (Abingdon, 2017), 7, 28-9. The terms of the treaty make it clear that the agreement related specifically to Bertrand's lands in Tripoli and surrounding area.

${ }^{61}$ This second document was concluded at Turin, but the text of the treaty does not carry any indication of place. Frederick's charters indicate that he was near Piacenza on 27 July and in the area of Turin by 6 August, and the treaty was concluded at some point before 1 August.

62 The treaty records that the Genoese ambassador came with the document and the seal to the king of Valencia 'here in this place', but the name of this place is not identified.

${ }^{63}$ The text refers to 'Boabdele Mahometo filius Saide', which likely referred to the governor of Valencia, Yusuf ibn Mardanish, or his brother Ibn Mardanish. See Hugh Kennedy, Muslim Spain and Portugal. A Political History of al-Andalus (London, 1996), 194-5.

${ }^{64}$ The text reads 'leulinus filius Ioruert'; that is, Llywelyn, son of Iorwerth. There is no mention of any specific title, but that Llywelyn ruled over Gwynedd in north Wales is certain.

${ }^{65}$ As per text. More commonly referred to as the kingdom of Navarre, which was centred on the city of Pamplona.

${ }^{66}$ The text refers to him as 'Almuktadir bille', that is Ahmad ibn Sulayman al-Muqtadir, often simply referred to as Moctadir or al-Muqtadir, who ruled the taifa (independent Muslim principality) of Zaragoza. Note that the Latin text does not refer to his title, although contemporary chroniclers call him rex (king). Perhaps implied by the Arabic bi-llah, rendered in the text as 'bille', meaning 'with/through God', and seemingly corresponding to the Latin 'Dei Gratia' (by the grace of God).

67 'populo Gaietano'.

${ }^{68}$ The date of this treaty has been much debated. For two examples, see Thomas F. Madden, 'The Chrysobull of Alexius I Comnenus to the Venetians: the Date and the Debate', JMH, 28 (2002), 23-41; Peter Frankopan, 'Byzantine Trade Privileges to Venice in the Eleventh Century: The Chrysobull of 1092', JMH, 30 (2004), 135-60.

69 The text does not specify but if the date is correct then the doge must have been Pietro Polani, who was doge until 1148.

${ }^{70}$ More accurately, the text records that the truce was concluded at a meeting between Verneuil and Tillière, on the river Avre, for which, see map 2 in Benham, PMA, 34. 